\title{
MAPPING THE TECHNOLOGICAL LANDSCAPE: \\ MEASURING TECHNOLOGY DISTANCE, TECHNOLOGICAL \\ FOOTPRINTS, AND TECHNOLOGY EVOLUTION
}

\author{
Barak S. Aharonson \\ Tel Aviv University \\ Business School \\ Strategic Management \\ 69978 Tel Aviv \\ Tel Aviv \\ Israel \\ aharonson@tau.ac.il
}

\author{
Melissa A. Schilling \\ New York University \\ Stern School of Business \\ 40 West $4^{\text {th }}$ Street \\ New York, NY 10012 \\ 212-998-0249 \\ Fax: 212-995-4235 \\ mschilli@stern.nyu.edu
}

We are grateful to Kathy Eisenhardt, as well as participants of the West Coast Research Symposium for helpful comments and suggestions. This research is supported by the National Science Foundation under Grant No. SES-0234075 and the Henry Crown Institute of Business Research in Israel. 
MAPPING THE TECHNOLOGICAL LANDSCAPE:

\title{
MEASURING TECHNOLOGY DISTANCE, TECHNOLOGICAL FOOTPRINTS, AND TECHNOLOGY EVOLUTION
}

\begin{abstract}
We develop and apply a set of measures that enable a fine-grained characterization of technological capabilities based on the USPTO database. These measures can capture the distance between any two patents, and help to identify outlier patents. They also provide a rich characterization of a firm's technological footprint, including its depth and breadth. The measures also enable researchers to assess the technological overlap, similarity, and proximity of the technological footprints of two or more firms. At the level of the macro technology landscape, the measures can be used to explore such dynamics as technology agglomeration, knowledge spillovers, and technology landscape evolution. We show applications of each of the measures and compare the results obtained with those that would be obtained with previously existing measures of firm diversity, similarity and proximity, highlighting the advantages of the measures used here.
\end{abstract}




\section{INTRODUCTION}

A firm's technological capabilities are central to its identity, its strategies, and its potential for success. Technological capabilities represent what the firm can do in the present, as well as what it has learned in the past. These capabilities also have a significant influence on the trajectories a firm will choose in the future. It is not surprising, then, that there are many streams of research that invoke the notion of technological capabilities, including (but not limited to) those that examine competitive positioning, innovation, organizational learning, diversification, and organizational growth. However, the development of measures for constructs such as technological capabilities, technology distance, technological similarity, and technology footprints is a nascent field, with much opportunity for further development.

Most of the prior work on such measures can be classified into four categories: 1) measured based on SIC codes, 2) measures based on patent classes, 3) measures based on patent citations, and 4) measures based on textual analysis of patents. Early work on technological relatedness tended to use industry classification (SIC or NAICS) codes, looking at, for example, a firm's business share across different SIC codes or the degree to which its combinations of SIC codes mirrored patterns in the general economy -- what Teece et.al (1994) term "corporate coherence." The advantage of this kind of approach is that one is not limited to examining only firms that patent. The main disadvantage of this kind of approach is its imprecision: First, most industry classification systems reflect markets in which a firm competes, not technological capabilities with which they compete. For example, SIC code 2043, "cereal breakfast foods manufacturer," tells us little about the technology (e.g., cooking, drying, extrusion, rolling, etc.) involved. By contrast, USPC mainline subclass 323.4 "cereal puffing by means of an apparatus adapted to 
subject cereal to sudden changes in pressure to disrupt the same and produce an expanded or inflated product" gives us considerably more technology capability-relevant information and offers greater precision. Second, SIC codes are typically only available at the firm level, and even then usually only at the "primary" SIC code level, which may mask considerable firm activity.

One of the most common approaches to handling technology distance or similarity is to count the number of patent classes two firms have in common across their patenting portfolios (e.g., Ahuja \& Katila, 2001; Diestre \& Rajagopolan, 2012; Dushnitsky \& Lenox, 2005). This method is relatively easy to implement and relies on publicly-held data that can be regularly updated, however the tradeoff for this efficiency is a loss of granularity and detail. This loss is particularly acute when researchers use only the first class listed on a patent (Benner \& Waldfogel, 2008). As we will show, measures based on patent subclasses provide a much richer and more reliable picture of a firm's technological capabilities.

There is also a significant body of work that measured technological relatedness by looking at whether firms (or patents) cite the same prior art. Some studies have recently highlighted challenges with using patent citations for measures of relatedness, however, because the citation of prior art is both discretionary and strategic, and the citation process was never designed to represent a taxonomy (e.g., Alcacer \& Gittelman, 2006; Benner \& Waldfogel, 2008). Furthermore, the patent citation process necessarily suffers from problems related to sequential interdependence: one can only cite work that has been made public previously, thus if patents are 
not assigned prior art citations at the same time, they draw from different opportunity sets of prior art.

Nascent work on textual analysis of patents by authors such as Gerken \& Moehrle (2012), Yoon \& Kim (2012) and Yoon, Park, \& Kim (2013) use the words and sentence structures in the patents to create a map of the technological positions and differences between patents. This is a very promising avenue of research that has the potential to yield rich maps of firms' technology capabilities. However, to create these measures, a researcher typically must understand the technological domains and their terms, synonyms and acronyms. As a result, this approach is usually deployed in a single narrow domain rather than across multiple technology domains.

Precise and fine-grained measures of technological capabilities might enable researchers to better characterize such features as a firm's technological footprint, how broad or specialized that footprint is, how distant its technological capabilities are from those of its peers (or how distant the technological capabilities of an alliance partner or acquisition target are from those of a given firm), how much the firm's technological footprint overlaps with those of competitors, etc. Such measures could also be used to better understand dynamic processes such as how a firm has developed over time, how diversification moves build upon or extend technological capabilities, or even the evolution of entire technological fields.

We thus develop and test here a set of measures that enable a finer-grained characterization of technological capabilities. These measures enable researchers to create a rich characterization of a firm's technological footprint, including its depth and breadth. The measures also enable 
researchers to assess the technological overlap, similarity, and proximity of two or more firms. The measures make it straightforward to see how a firm's moves relate to its existing technological capabilities, such as whether an acquisition enhances an existing technological strength or represents an extension into related or unrelated fields. At a macro level, the measures can be used to explore knowledge spillovers, such as how the existence of intellectual capital about a particular set of technologies influences the growth of intellectual capital in adjacent technology positions. Our approach also provides a method of identifying and demarcating industry boundaries in a way that is not always clearly captured by conventional industry classification systems. This may be particularly useful for understanding the emergence of (and relationships between) nascent industries.

We begin by explaining the notion of recombinant search on a technology landscape, and then develop a set of measures of technology positions on that landscape that permit us to create finegrained measures of technological distance and technology footprints. Though the concept of a technology landscape underlies much of the work on recombinant search and innovation (e.g., Ahuja \& Katila, 2004; Fleming \& Sorenson, 2001, 2004; Kauffman, Lobo \& Macready, 2000; Rosenkopf \& Almeida, 2003), only a few studies have attempted to examine what the actual technology landscape looks like or how technology positions grow within it (e.g., Podolny and Stuart, 1995; Stuart and Podolny, 1996; Schoen et al, 2012). Like their work we utilize patent data to characterize the technology landscape; unlike their work, however, we do not rely on patent citations to represent the knowledge a firm has or builds upon, nor are we constrained to a particular industry. To develop our measures, we first use a novel technology distance measure to map the entire database of USPTO patents filed from 1976 to 2012, identifying every 
occupied technology position and its distance from other occupied technology positions. In so doing, we have created a dataset that will be available to academic researchers through a webbased interface. We then show how those technology positions can be used to calculate technological distance, and to assemble technology footprints of firms. These measures, in turn, can be used to assess such dimensions as technological concentration, technological similarity, technological proximity, and other useful measures that can be applied at the patent level, technology position level, firm levels, or population levels.

\section{RECOMBINANT SEARCH ON A TECHNOLOGY LANDSCAPE}

The world of potential technological innovations can be conceived of as a landscape, with each potential position on the landscape corresponding to a particular configuration of components (Fleming \& Sorenson, 2004; Kauffman, Lobo, \& Macready, 2000). Each position may or may not be occupied by existing innovations; some positions are more feasible or valuable than others, and some positions are potentially feasible or valuable but innovations have not yet been discovered in them. Furthermore, the distribution of innovations across this technology space is unlikely to be either random or uniform. Instead, for reasons we will discuss in the paper, innovations are likely to agglomerate into clusters of adjacent technology positions.

The process of exploring different potential solutions to a problem, including the identification of new knowledge elements or new relationships between knowledge elements, is often termed recombinant search. Recombinant refers to the fact that the creation of new knowledge is most often the result of novel recombinations of known elements of knowledge, problems, or solutions (Gilfillan, 1935; Nelson \& Winter, 1982; Penrose, 1959; Schumpeter, 1934; Usher, 1954) or the 
reconfiguration of the ways in which such knowledge elements are linked (Henderson \& Clark, 1990; Henderson, 1994). Nelson and Winter (1982: 130) provide a cogent summary of this argument: "innovation in the economic system - and indeed the creation of any sort of novelty in art, science, or practical life - consists to a substantial extent of a recombination of conceptual and physical materials that were previously in existence."

\section{Technological Distance and Agglomerations}

Much of the research on recombinant search implicitly or explicitly utilizes a spatial metaphor. Reference is made to searching in the "neighborhood" of past solutions (Cyert \& March, 1963) or practicing "local" or "distant" search (Nelson \& Winter, 1982). Such a conception of search invokes the notion of a technology landscape, characterized by peaks of opportunity wherein particular combinations of knowledge elements yield valuable new solutions, and valleys wherein particular combinations of knowledge components are unlikely to be useful. Most of this technology landscape is unknown to individual inventors or firms, leading firms to focus on only the familiar portions of the technology landscape, i.e., the technological elements (and combinations of elements) with which they have prior experience (Sorenson \& Fleming, 2004; Stuart \& Podolny, 1996). This is one of the primary explanations for the prevalence of local search. The more knowledge and experience an inventor has in a particular domain, the more likely they are to understand the nature of the relationships between different technological elements, and the more efficient the inventor should be in searching for a useful combination (Cohen \& Levinthal, 1990; Dosi, 1988; Harlow, 1959). Furthermore, to the degree that inventors can learn through observing the value of technology combinations made by others, inventors might reap some advantages of local search by searching in the vicinity of other inventors' 
experience. In essence, any inventor's progress up an opportunity peak provides valuable guideposts for other inventors to follow. The amount of innovative activity in the vicinity is likely to both be an indicator of the perceived quality of the underlying opportunity, and serve as a reservoir of knowledge from which the inventor can draw.

We have focused on the core knowledge-based arguments for how new technology positions emerge and "bloom." There are, of course, other more idiosyncratic or strategic reasons that patents accumulate in a given area, particularly as the technology position matures. A high level of patenting in a technological area might indicate that the technology is complex with many distinct areas for invention, or that there is a high level of design substitution and uncertainty resulting in multiple permutations being patented (Anderson \& Tushman, 1990; Schilling, 1998). It may also indicate control of the intellectual property in the area is being hotly contested through patent races or thickets (Hall \& Ziedonis, 2001; Ziedonis, 2004; von Graevenitz, Wagner \& Harhoff, 2013). All of these processes typically imply (with some interesting exceptions) that inventors think that the area represents a valuable opportunity, and this is this common denominator that we focus on here.

This suggests an increasing returns argument: the more innovation that has previously occurred within a technology position, the more rapidly will innovation in the technology position grow. However, it is also probable that such increasing returns do not last indefinitely. The continuous exploitation of familiar knowledge combinations can exhaust their potential as sources of novel solutions because all possible variants are eventually achieved (Fleming, 2001; Kim \& Kogut, 1996). This argument is highly consistent with work on s-curves in technology improvement 
(Ayres, 1994; Christensen, 1993, 1994; Foster, 1986; Twiss, 1992). When the performance of a technology is plotted against the amount of effort and money invested, it typically shows slow initial improvement, then accelerated improvement, then diminishing improvement. Performance improvement in the early stages of a technology is slow because the fundamentals of the technology are poorly understood. Great effort may be spent exploring different paths of improvement or in exploring different drivers of the technology's performance. However, as scientists or firms gain a deeper understanding of the technology, improvement begins to accelerate. Developers of the technology target their attention towards those activities that reap the greatest improvement per unit of effort, enabling performance to increase rapidly. However, at some point, diminishing returns to effort begin to set in. As the technology begins to reach its inherent limits, the cost of each marginal improvement increases, and the s-curve flattens out. Scurves of technological improvement have been well documented in a wide range of technologies, including disk drives, automobiles, sailing ships, semiconductors, vacuum tubes, steam engines, and more (see Foster, 1986 or Ayres, 1994, for a range of interesting examples).

For any given technology position, there are numerous adjacent potential technology positions (i.e., those that differ by only one component). Firms that innovate within a technology position are likely to be in a good vantage point to identify opportunities in these adjacent technological positions. Furthermore, the commonality between a position and its adjacent positions suggests that the knowledge in any given position will, to some degree, also be useful in adjacent positions. More generally, the closer the distance between two technological positions the greater the similarity between the technological components that define the technology positions, and thus the greater the likelihood of knowledge spillovers between the two positions. We therefore 
expect that technology positions will tend to be agglomerated on the technology landscape, with clusters emerging and spreading as firms identify opportunities in adjacent positions. We later show this dynamic empirically using longitudinal data on a cluster of technology positions.

It is also possible, however, for inventors to pioneer uncharted territory in the technology landscape. Inventors might stumble upon a new peak through serendipitous discovery, such as in 1928, when Alexander Fleming noticed how a spot of mold on a laboratory culture of bacteria was surrounded by an area in which the bacteria did not grow, leading to the development of antibiotics (Koestler, 1964). Scientific theory may also give inventors foresight into potentially valuable areas of the technological landscape. For example, Sorenson and Fleming (2004) provide an example of researchers predicting that single-wall carbon nano-tubes would either conduct or semi-conduct, depending on the angles of the carbon bonds. This helped inventors to target a specific position on the technology landscape that was previously unknown, and that gave rise to new generation of chip technology. Sorenson and Fleming (2004) thus argue that science can, in essence, provide a map that guides technological search in unknown areas of the technology landscape. Our metrics are useful here also, as they provide a straightforward way of identifying "outlier" patents - patents that pioneer uncharted territory in the technology landscape.

It should be noted that while our arguments about knowledge spillovers appears highly analogous to the considerable body of work on geographical agglomeration that posits that geographic proximity enhances knowledge spillovers (e.g., Almeida \& Kogut, 1999; Almeida, Dokko \& Rosenkopf, 2003; Audretsch \& Feldman, 1996; Chung \& Alcacer, 2002; Feldman, 
1994, 2003; Jaffe, Trajtenberg \& Henderson, 1993), the spillover mechanisms are different. In geographical agglomerations, spillovers occur because geographic proximity facilitates the transfer of knowledge through such factors as personnel mobility, greater opportunities to collaborate with direct face-to-face contact, etc. In technological agglomerations, spillovers occur because of knowledge relatedness - the commonality of knowledge between two technology positions increases both the relevance of the knowledge of one position to another, and the ease with which it may be applied.

\section{MEASURES AND THEIR APPLICATIONS}

We now turn to showing how we can use the previously defined conceptualization of technology positions on a technology landscape to create a system of measures for assessing the distance between technologies, the characteristics of a focal firm's technology footprint and its similarities and differences with other firms, and the evolution of technologies in a given domain over time.

\section{Measuring the Distance between Technology Positions}

To measure technological distance, we begin by creating a binary technology vector for each potential technology position in the USPTO database based on their mainline subclasses. The U.S. Patent Classification (USPC) system is designed to provide a storage and retrieval system for the U.S. patent database that helps examiners identify which documents they need to review when examining patent applications. As such, it was intended to be exhaustive of all patentable subject matter. There are five main bases of classification: industry or use, proximate function, effect or product, structure, and a "multiple aspects" basis that was created to address the 
shortcomings of categorizing patents according to only a single basis. One of the fundamental principles of the USPC is that classes are based on the analysis of the U.S. patents and their disclosed claims rather than some theoretically ordered system. That is, its structure is in essence empirically derived from the claims made in the patents, and as a result, the U.S. classification of utility patents is oriented towards addressing the functional or technological orientation of the patent. As of 2014 there were 473 patent classes, about 10,000 main subclasses, and more than 200,000 total subdivisions. The subclasses are arranged in a hierarchical structure starting with class, followed by a main subclass and continues with the subdivisions until it reaches an efficient categorization of the patent aspect being addressed. Each patent is assigned to one or more classes and/or subclasses according to the bases of classification described above.

Because innovation results in uneven growth across different technological categories, and spawns categories not originally anticipated, the USPC system is occasionally refined and patents are reclassified. The reclassification process involves the changing of the classes and subclasses to which the patent documents are assigned, including those patent documents assigned in the past. The reclassification process is a "necessary correction" to ensure the efficient search and assignment of the technologies. As the number of documents classified in a class or a subclass grows and the breadth of the technologies covered by those documents becomes more diverse, the search and the assignment become less efficient and less meaningful. Hence, as the USPTO notes, new classes and subclasses are created to "cover newly evolving technologies", to address the evolving changes of the innovations themselves and the technologies on which they are based. The reclassification of the older patent documents ensures that the data remain harmonized. 
The fact that patents are reclassified means that when researchers use data based on patent classes they must ensure that they are using a consistent classification system throughout their dataset, unless their core purpose is to study reclassification itself. Using different classification systems within a study could create erroneous variance. For most purposes, it makes sense for researchers to use the most recent classification that is available. We have used the most recent classification (end of 2013) available at the time our patent data was collected.

Notably, U.S. patents are also classified according to the World Intellectual Property Organization's (WIPO) International Patent Classification (IPC) system. The IPC system was established by the Strasbourg Agreement in 1971, and entered into effect in 1975. Examiners in each country are in charge of classifying the patents in their domain to the relevant IPC scheme. Accordingly, in the U.S., the examiner who classifies patents according to the U.S. classification system is the same one who classifies patents by the IPC system. The key differences, then, are due to the differences in structure and philosophy of the two systems. The IPC system has significantly fewer subdivisions and thus yields a less fine-grained classification, and is generally considered to be more industry focused, compared to the USPC which assigns classes also on structure, function, etc. (Harris, Arens \& Srinivasan, 2010). Because our focus here is on capturing technological capabilities in a precise way, the USPC is a much better system for our purposes.

We count each mainline subclass (the subclasses identified in bold under the class designations in the Manual of Patent Classification) as an individual component of a technology vector. This approach builds on the method used by scholars such as Jaffe (1989), Jaffe et al. (1993), Kotha, 
Zheng \& George (2011) and Lerner (1994, 1995), but rather than relying on the roughly 473 main (3-digit) classes used in these studies, our vectors are much finer-grained as we use each of the 9864 mainline subclasses to identify components of the technology vectors. Furthermore, by using all of the mainline subclasses listed for each patent, and using the entire USPTO database, we avoid problems that can arise in measures based on only the first listed class or measures derived from small samples of patents (Benner \& Waldfogel, 2008). For a given patent, each component can take the value of one (if the mainline subclass is listed for the patent) or zero (if the subclass is not listed for the patent). Because there are 9864 mainline subclasses in total, the technology vectors are 9864 digits long and there are $2^{9864}$ potential technology positions. Many of the theoretically possible technology positions, however, are unlikely combinations of components. In 2012 , only $1,968,141$ of the potential technology positions were occupied by patents.

Next, we create an empirically-derived fine-grained measure of technological distance that makes rich use of the existing patent data. We start by defining technology positions as "adjacent" when they differ by only one component of the vector. For example, the vectors 00011100 and 00001100 are adjacent as they differ only in the value taken by the fourth component. We then use a network algorithm to calculate the path length between every pair of occupied technology positions based on these adjacencies. Once a list of vector pairs that have a distance of one, has been created any shortest path algorithm can be used to obtain the path lengths (e.g., Dijkstra's algorithm, A*search, Floyd-Warshall algorithm, etc.). For a smaller subset of the data, the calculation of the path length can be done using UCINET or Pajek. Because we are working with a very large dataset, we used a custom-created $\mathrm{C}++$ algorithm and 
then checked our results for subsets of the data against results obtained using UCINET to verify the validity of the algorithm. An example of the path length calculation, if there were only three occupied technology positions in the universe with the following vectors, a) $00011100, \mathrm{~b}$ ) 00001100, and c) 00011000, the technological distance between position b and position c would be two, as each is adjacent to position a. In our calculations we do not use mere overlap of a single component to establish adjacency as this would cause some widely used subclasses to create an artificially short distance between technologies that are actually quite different. If multiple years of data are being compared, this path length measure should be computed for each year to reflect the changing technological landscape, i.e., as new positions on the technology landscape become occupied, the path length between two patents can shorten.

For an example of the use of this measure, Table 1 shows ten patents by ten different firms, with path lengths as of 2008. Each patent is located in a particular position in the technology landscape based on its vector of components. The matrix shows the path length between each of those positions. The matrix indicates some distances that would be consistent with our intuition, and some surprises. For example, it is probably not surprising that the medical device patents are located in positions that are quite close to each other. It is similarly logical that the microprocessor patent occupies a technology position that is relatively close to that for a $\mathrm{RAM} / \mathrm{ROM}$ patent, and relatively far from that of a Biotech method patent. It is somewhat less intuitive, however, that RAM/ROM would be closer to the medical devices than to the computer mouse or LCD patents. The matrix also reveals that the biotech method patent is, at least among this group of patents, an outlier. It has much further path lengths to the other patents. 
Our approach bears some resemblance to the approach used by Schoen et al (2012). In their study, they use 389 main IPC classes used in a specific industry. If two patents are assigned to the same IPC class, this is treated as a connection, and the resulting connections are used in a based on the number of times a pair of classes appear together in the same innovations in the industry. While their approach provided important information based on market classification, we suggest that if such a map would be created using the subdivisions of the classification scheme (to depict nodes (the sub-classes), their size (number of times the classes were used in the industry), and the distance between them), it would provide more detailed knowledge about the technological landscape. However, as there are many more components that need to be incorporated this would entail substantially increased complexity and could not be as easily depicted on a page. Schoen et al (2012) approach uses the IPC classification system, which is more focused on whether patents co-appear in the same industry. Our approach, focuses more on technological components. That is, two innovations used in the same industries but based on fundamentally different technologies will appear much more similar with the Schoen et al (2012) approach; two innovations that are technologically similar but used in different industries will appear much more similar with our approach network algorithm to map the technological landscape.

We posit that the technology distance measure we proposed here is very useful for thinking not only about how two or more patents relate to each other, but also for assessing various features about the technology footprint of a focal firm, or the similarities and differences between multiple firms, as will be shown in the next section. 


\section{Technological Footprints}

By identifying the technology positions occupied by all of the patents filed by a firm (or the patents filed by a firm within a particular time period of interest), one can obtain a technological footprint of the firm that shows both the spread of terrain covered, and the depth of repeated search in particular areas of that terrain. Consider the technology footprints of the medical device companies shown in Tables 2 through 4 (due to space constraints, only the range of subclasses in which the firm is active is shown; the vectors would show zeros in the subclasses not shown). Insulet Corporation manufactures insulin pumps that adhere directly to the skin. As of 2009, this company had sixteen patents and occupied five unique technology positions. Xtent manufactures drug eluting stents for treating arterial lesions. As of 2009, it had 18 patents, and occupied five unique technology positions. Aptus Endosystems develops stents and related devices to treat aortic aneurisms. As of 2009 it held nine patents, and like the others, occupied five unique technology positions. With these footprints, we can assess how concentrated a firm's technological capabilities are, and how proximate or similar they are to other firms' sets of technological capabilities, as elaborated below.

Concentration. A simple measure of the scope of a firm's technological capabilities can be obtained by simply counting the number of technology positions in which the firm is active (or technology components, depending on the purposes of the researcher). However, a concentration measure provides a better sense of whether the firm prefers to search deeply in one or a few areas, or is more inclined to spread its technological activities over a wider range of technology domains. The concentration of firm's technology activities can be calculated with a Herfindahl 
Hirschman Index of the share of its patents in each technology position, i.e., the sum of the squared percentage of patents that are in each technology position. Thus if a firm has ten patents, and seven of those ten (70\%) are in the same technology position and three of those ten $(30 \%)$ are in another, the firm's concentration of technology activities would be $70^{2}+30^{2}$ which equals 5,800 . This measure achieves its highest value when all of the patents are in the same technology position, or $100^{2}$ which equals 10,000. Insulet's concentration equals 5000. Aptus Endosystems has a concentration of 2839.51. Xtent's concentration equals 3950.62. The measure thus indicates that Insulet is significantly more technologically concentrated than the other two firms. A traditional concentration measure based on industrial classification codes would have not revealed this nuanced difference in the firms' technological footprints, as all three firms reap $100 \%$ of their revenues in a single six-digit NAICS code (Insulet - 339112, surgical and medical instrument manufacturing; Xtent and Aptus Endosystems - 339113, surgical appliance and supplies manufacturing).

Technological Proximity and Similarity. The technology footprints can also be used to calculate the proximity and similarity of two or more firms. In the existing literature on technological capabilities or technology niches, the concepts of technological proximity and technological similarity are often used to convey the same idea, though in other realms it is clear that the two constructs are quite different. Proximity refers to nearness, whereas similarity typically refers to degree of commonality. While some measures pertain to both similarity and proximity (such as overlap), other measures are more specific to one or the other. The differences are aptly illustrated in the examples below. 
The technology footprints described above can be used to calculate several measures of technological proximity and similarity between firms; which is more relevant depends on the purposes of the researcher. First, researchers may be interested in the degree to which two firms have technology footprints that overlap. A number of researchers have measured technological overlap by looking at the degree to which firms' patents cite the same body of prior art (e.g., Kapoor \& Lim, 2007; Podolny \& Stuart, 1995; Sears \& Hoetker, 2013). This approach, however, suffers from some potential limitations. First citations may not always offer a full account of the technology underlying the patent. Inventors and patent examiners have some discretion in their decision about which prior art to cite (Alcacer \& Gittelman, 2006), and citations are included for the purposes of clarifying and limiting the claims in a patent. They are not intended as a typology system for patents. If a component or function is highly novel there may be no prior art to cite for it (and an inventor may desire to make it appear as if this is the case). Though it is possible to make a similar argument that a component or functionality could be so novel that a patent classification code does not exist for it, the difference is in this intentionality: the patent classification system is intended as an exhaustive typology system to organize patents, and thus examiners attempt to assign classification codes that completely capture the invention's structure and purpose. Second, measures based on citations suffer from an acute problem due to sequential interdependencies, i.e., a patent can only cite art that is, by definition, published earlier, thus lowering the likelihood that any two patents not filed at the exact same time cite the same body of prior art. 
We measure technological overlap by looking at overlap in the components of the patents themselves. This helps to avoid problems that may emerge due to differences in citing norms (i.e., some firms may cite more prior art than others) or sequential interdependence. For example, Xtent and Aptus Endosystems overlap in two technology positions (the position characterized by a single mainline subclass, $623 / 1.1$, and the position characterized by the two mainline subclasses, 623/1.1 and 606/1). For Xtent, this means that $78 \%$ of its patents overlap with those of Aptus Endosystems, and 67\% of Aptus Endosystems' patents overlap with those of Xtent's. It is important to recognize the asymmetric nature of overlap; if a small or highly specialized firm has a large percentage of its patents in a technology position shared with a much larger or more diverse rival, the overlap for the former will be large and may represent a serious competitive threat whereas the overlap for the latter firm may be trivial. This is in line with Podolny and Stuart (1995) arguments about asymmetrical niche overlap.

More nuanced measures of proximity can be derived by utilizing the technology distances between the positions represented in the firms' technology footprints. The simplest of these is the minimum distance of the firms' technology activities. If two firms each have a patent in a shared technology position (which we previously referred to as "technological overlap"), their minimum technology distance is zero. Xtent and Aptus Endosystems, for example, overlap in multiple technology positions and thus have a minimum distance of zero. This approach is similar to measures proposed by Bar and Leiponen (2012) and Diestre and Rjagopalan (2012), though whereas their measures are based on classes, our measures are based on the finer granularity offered by subclasses. However, knowing whether two firms have overlapping technology positions does not really capture the overall technological proximity of the two firms. 
We can thus also measure the average pair-wise distance between every pair of technology positions occupied by two or more firms, using the path lengths obtained with the network algorithm described earlier. The average pair-wise distance between every technology position occupied by Xtent and Aptus Endosystems is .38, indicating that the technology footprints of the two firms are highly proximate.

We might also be interested in the degree to which the technology footprints of the two firms are similar in shape, i.e., emphasizing the same technology activities with corresponding proportions. If we assume that each component of a technology vector corresponds to an underlying technology capability or activity, then we can compare the distributions of each firm's presence in those technology components. In this case, we would aggregate the technology vectors represented by all of the individual patents into a single binary string for each firm (i.e., we include all the subclasses for which both firms would show zeros) as in Table 5. We can then calculate a pair-wise correlation between the two firms. The pair-wise correlation between the distribution of subclasses represented in the patents of Aptus Endosystems and Xtent is .82 , which is very high (and significant at the $\mathrm{p}<.01$ level). By comparison, a similarly constructed correlation between Aptus Endoystems and Insulet is -.00, and between Xtent and Insulet is -.11 . Neither are significant. This measure thus provides a robust metric of our intuition that the technological capabilities of two companies specialized in the development of arterial stents will be more similar than technological capabilities of a stent producer and an insulin pump producer. 
The calculation of a pair-wise correlation between the technology vector of two firms is similar to one used by Gilsing et al (2008). However, while our use of the subclasses rather than classes is more complex to assemble it offers a finer-grained perspective. It is important to note that Gilsing et al's (2008) approach emphasizes the use of time windows to capture a temporal perspective on the firm's knowledge, which we believe should be incorporated when calculating a pair-wise correlation between the technology vector of two firms as well as for other technological measures.

Each of these measures has advantages in particular research contexts. If, for example, a researcher is interested in evaluating whether a bidding firm and target firm have related capabilities, the minimum distance measure or footprint overlap might be most useful. On the other hand, if a researcher wanted to identify firms that occupy similar competitive positions, then the average pair-wise distance measure or the similarity in shape measure would be more informative. It should be immediately apparent that these measures provide a much finer-grained assessment of technological proximity and similarity than typical measures (e.g., industrial classification codes, benchmark input-output data, patent counts in particular classes, accounting-data based measures, etc.).

By calculating these measures at multiple points in a firm's (or firms') history, one can see how a firm's technology capabilities and activities have evolved over time, and how this evolution has made them more similar to (or different from) particular competitors. The measures can also be used to assess the density of competitors in a particular technological space. For example, a 
researcher may wish to identify how many firms occupy a given technology position or are active within a finite distance from that position.

\section{Exploitation versus Exploration}

A wide body of research draws on the ideas of exploration versus exploitation in recombinant search. In the management and complex adaptive systems literatures, exploration refers to the search for new, useful adaptations, and exploitation refers to the use and propagation of known adaptations (Holland 1975; March 1991; Mitchell 1996). Although exploitation yields more certain and immediate returns, it makes the discovery of truly novel solutions unlikely and can lead to obsolescence in the long run (Fleming, 2001; Schilling \& Green, 2011). On the other hand, while exploration can enable the discovery of profoundly novel solutions, it also typically causes a degradation of performance in the short run because searches for novel solutions usually fail. The technology footprint measures already provide some sense of whether a firm prefers to search repeatedly in familiar domains or tends to search more broadly. However, we can also use the methods here to evaluate whether a firm has successfully explored unlikely technological combinations, or to identify "outlier" patents or "outlier” firms. For example, by looking for patents that occupy technology positions with no adjacencies at their time of granting, one can identify technology combinations that that were somehow unusual at the time they were created. One such patent, for example, is held by Nexia Biotechnologies: patent \# 5780009 -- Direct gene transfer into the ruminant mammary gland, filed in 1995 and granted in 1998. This patent combined several classes of technologies related to in vivo testing with two more unusual classes related to methods of creating a transgenic nonhuman animal and methods of using transgenic animals to create proteins. This combination of classes made it the first patent to occupy 
technology position 1820021, which had no adjacencies until Nexia filed a second patent later that year, patent \#590708 - Method for development of transgenic goats. This company went on to become famous for inventing the "spider goat" - a goat that lactates spider silk proteins that can be spun into "BioSteel," a remarkably strong and lightweight material (spider dragline silk is five times as strong as steel by weight). Nexia hoped to use the material in applications as diverse as bulletproof vests and medical sutures.

There are other ways to identify outlier patents. As noted previously, numerous studies have looked at the degree to which patents cite the same prior art as a measure of their similarity or relatedness to other patents (e.g. Jaffe, Trajtenberg \& Henderson, 1993; Thompson \& Kean, 2005). One of the major drawbacks to this approach for identifying outlier patents, however, is that even very unusual patents can cite significant bodies of prior art that may constitute knowledge building blocks that have been built upon, and to the degree that this prior art overlaps with that used by others, this approach may fail to identify outliers. Recent advances in text analysis methods have also led to a flurry of new text-based approaches to identifying similarities between patents based on keywords extracted from the patents, or more complex semantic patterns exhibited in the patent text (see for example, Moehrle, 2010; Gerken \& Moehrle, 2012; Yoon \& Park, 2004; Yoon \& Kim, 2012). In general, these methods provide a very fine-grained way to identify commonalities between patents, at the cost of being more difficult to apply on a large scale. Handling the text of patents is considerably more data intensive than handling their classes and subclasses, and sophisticated techniques must be used to avoid error due to semantic divergence (i.e., a single concept might be expressed in multiple ways), and semantic convergence (i.e., multiple concepts might be expressed in similar ways). 
Such an approach is thus probably best suited to deep explorations of a relatively narrow technological area.

Many outlier technology positions will not garner much attention, and will remain lonely isolates on the technology landscape. However, others will grow and bloom into exciting areas of technological inquiry over time. We show how the measures here can be used to examine such technology lifecycles in the next section.

Table 6 summarizes and compares our measures along with some of the notable measures developed in previous studies.

-Insert Table 6 About Here-

\section{RESEARCH APPLICATION 1: TECHNOLOGY LIFECYCLES}

By examining a technology position and its "neighborhood" (the technology positions that exist or emerge near to the focal technology position) over time, one can glean considerable information about the lifecycle of the technology position. For example, consider the pictures in Figure 1 that depict the evolution of technology position 17788 and its neighborhood over time. The nodes in the graph correspond to technology positions, and the links indicate adjacencies (i.e., two positions are adjacent if they are different in only one component). The sizes of the nodes are scaled by how many patents are in the technology position. The position 17788 , which first appeared in 1979, was one of the early biotechnology positions. It corresponds to a combination of the following "mainline" patent classes: 
434/4 - Measuring or testing process involving enzymes or micro-organisms; composition or test strip therefore; processes of forming such composition or test strip 434/41 - Micro-organism, tissue cell culture or enzyme using process to synthesize a desired chemical compound or composition 536 - Organic compounds

In 1979, technology position 17788 had four occupied adjacent technology positions ("near neighbors"): $17217,17417,22172$, and 24311 , each with only one patent. Over the years that followed, however, a large technology cluster bloomed in and around technology position 17788 . Many more patents were filed with similar technological components, causing technology position 17788 and its neighbors to grow (by 1989 there were 24 patents in technology position 17788) and to accumulate more near neighbors.

\section{-Insert Figure 1 About Here-}

Using this method to examine technology positions over time could be very useful for a number of objectives, such as comparing the rate of growth of different technological domains, identifying technological spillovers, assessing whether particular firms have served as "anchor tenants" that attract other firms to technology domains, and more.

\section{RESEARCH APPLICATION 2: ANALYZING A MERGER}

In this section, we apply the measures herein to publicly-available data on an acquisition that took place in 2005 to illustrate some of the differences in the outcomes obtained by using our technology position measures versus more traditional measures used in the strategy and innovation literatures. 
On July 28, 2005, Polatis Limited announced it would acquire 100\% of the assets of Continuum Photonics. Polatis was founded in 2000 in Cambridge, UK, and Continuum Photonics was founded in 1998 in Billerica, Massachusetts. Both companies were photonics companies that made high performance optical switches and were known for their piezo-electric beam steering. The companies merged their personnel and product lines in September of 2005 to create a single business (under Polatis' name). According to Aaron Bent (VP of Marketing at Continuum), the two companies had "similar base technologies" but had focused on somewhat different, albeit complementary, applications. Continuum had focused on optimal automation to make test labs more efficient. Polatis had used its "Micro-Actuation and Sensing System" to create very stable switches that were popular for the defense market. Together, they would be better positioned (and capitalized) to provide a full range of optical switch components and systems for the defense, data networking and telecommunications industries.

In 2005, when the two companies merged, Continuum Photonics' patents occupied four unique technology positions, and Polatis' patents occupied three unique technology positions, suggesting that both firms had relatively narrow technological scopes (see Table 7). Photonics had eight of its twelve patents in a single technology position, however, leading to a higher technology concentration score (HHI of 5000 versus Continuum's 2776).

We next assess the proximity and similarity of their technology footprints. The companies exhibit high degrees of technological overlap: the technology positions within which Polatis had filed (ultimately granted) patents exhibited $87 \%$ overlap with the technology positions occupied 
by Continuum Photonics (only two patents were in positions that were not occupied by Continuum) (see Table 7). Similarly, Continuum Photonics had only a single patent in a technology position not occupied by Polatis, thus $83.3 \%$ of its patents overlapped in technology positions with Polatis, suggesting the firms are quite proximate. Notably, replicating our process using the International Patent Classification system (creating vectors based on codes at the "Main Group" level) yields very similar results (see Table 8): All of Continuum's patents are in technology positions occupied by Polatis (100\% overlap), and all but four of Polatis' patents are in technology positions occupied by Continuum (73\% overlap).

-Insert Tables $7 \& 8$ About Here-

Furthermore, if we aggregate the technology vector of each, and then correlate these aggregated vectors, we find a .80 correlation between the companies, again suggesting that the firms are highly similar in their technological emphases. These measures collectively yield a picture of two firms that are technologically highly related, and we have multiple dimensions upon which to have faith in this assessment.

We now compare this outcome to other oft-used measures of technological diversity and relatedness. First, both companies were privately held, indicating that the most typical method of evaluating technological relatedness (using a database like Compustat to identify the firms' sales segments by SIC code, for example, as in Teece et al., 1994) would not have been possible, precluding the use of popular measures such as the entropy measure or the Herfindahl Hirschman Index for calculating diversification. This highlights an important trade-off between the methods developed here versus sales-based SIC methods: The measures here can be calculated for 
privately-held firms, vastly increasing the population of firms that may be considered. On the other hand, these measures will only be applicable for industries that emphasize patenting. One can, of course, find industry classification code estimates for privately held firms from such databases as Hoovers or Thomson's SDC. These sources provide only a single code for the firm, which means they cannot be used to assess the technological diversity of the firm, but they might be useful in assessing the technological relatedness between two different firms. Unfortunately, these codes are approximations made by the coders, and are not as reliable as one would hope. Hoovers, for example, listed Polatis as belonging in the SIC code of 3679 "Electronic components not elsewhere classified" (which is a reasonable approximation), and listed Continuum Photonics as belonging in 4841 "Cable and other pay television services" (which does not appear to be a good approximation). Based on these measures, we probably would not conclude the two firms were technologically related. SDC listed both firms as belonging in SIC code 3577 "Computer peripheral equipment not elsewhere classified," which though a coarse characterization, at least permits the possibility that the two companies might be technologically similar. It is also possible to use a concordance system between patent classifications and industry classification codes to emulate the measures above (see, for example, Silverman, 2002). Such an approach resolves the private firm problem, though it can introduce errors (e.g., there is not a one-to-one mapping of patent classes to industry codes thus weighting schemes are adopted to approximate such a relationship), and does not permit the kind of precision of technological identification achieved with the measures here.

A second class of measures with which to compare are those based on patent citations. Though we do not know of use of patent citation measures for assessing technological diversity at the 
firm level, patent citations have been used to assess technological relatedness, as mentioned previously in our section on identifying outlier patents. For instance, as mentioned earlier in the paper, Sears and Hoetker (2013), Podolny and Stuart (1995), and others identify technological proximity by assessing the degree to which firms overlap in the prior work they cite in their patents. While this approach is much more rigorous than early SIC-based measures, there remain some limitations, including: a) the fact that there can be many possible instances of relevant prior art, and a firm (and/or examiner) may choose only a sample, and b) patent citations are sequentially dependent (i.e., a patent can only cite art that is, by definition, published earlier), thus lowering the likelihood that any two patents not filed at the exact same time cite the same body of prior art. We replicated the patent citation overlap measure using all of the patents filed by Continuum Photonics and Polatis in the five years leading up to and including the year of the merger (consistent with Podolny and Stuart's 1995 specification). We found that 45 of Continuum's 217 prior art cites were also cited by Polatis, and 72 of Polatis' 187 prior art cites were cited by Continuum, for an aggregate citation overlap of $29 \%$. It is interesting to note that despite the fact that Polatis had twice as many patents filed during that time period, it cited less prior art than Continuum Photonics. This is surprising given the technological similarity of the two firms and the proximity in time in which the two firms were patenting. This raises the possibility that the amount of prior work cited can be quite variable, which could further depress measures of technological overlap. By contrast, the variability in patent classification, while not non-existent, is significantly lower. 


\section{MANAGERIAL DECISIONS AND THE TECHNOLOGICAL LANDSCAPE}

Many managerial decisions today necessitate understanding the technological landscape, such as assessing the firm's own and its competitors' positions, in which technologies to invest in development, with whom to partner, and the valuation of potential mergers and acquisitions. Managers of technology oriented organizations make decisions in highly complex and dynamic environments. Decisions such as in which technologies to invest entails allocating resources, often with little to no confidence about the outcome of the R\&D. The complexity of these decisions is further compounded by additional commercial issues and uncertainty relating to the technology in question (Ahuja, Lampert, and Tandon, 2013). Researchers have often stressed that managers use complex routines to address increased uncertainty (Zollo and Winter, 2002; Winter, 2003).

Cyert and March (1963), in their seminal work on the behavioral theory of the firm, propose a model for managerial decision making that stresses that managers need to understand and be able to evaluate their competitive environment. The model calls for understanding the capabilities of the firm to the degree that it can address its objectives and formulate alternative strategies. Others researchers highlighted the important role of fine-grained search in the decision process (Carter, 1971). Taking this view of the decision process in the context of the firm's technology, our methodology can help managers assess the firm's relative competitive technological position and provide managers with alternative ways of thinking about their potential technological trajectories. Cyert and March (1963), further explain that managers formulate the firm's objectives and aspiration levels based on the firm's prior performance as well as that of its competitors. Studies that followed suggested that managerial risk taking is influenced by the 
degree to which the firm was able to attain its aspiration levels (for example Chen and Miller, 2007; Iyer and Miller 2008; Wiseman and Bromiley, 1996). Thus, to formulate their objectives as well as help in assessing some of the risk involved in new technological R\&D, managers require tools that facilitate in-depth analysis of the technological landscape.

Taking a contrasting perspective, Eisenhardt (1989) has argued that while effective decision makers develop strategic alternatives, they rarely fully analyze them. Eisenhardt and Zbaracki (1992) suggested that the traditional decision studies that emphasize the comprehensiveness of the decision process may not be as useful for mangers of firms in an unstable environment. They further argue that managers face cognitive limits and "decision makers satisfice instead of optimize, rarely engage in comprehensive search, and discover their goals in the process of searching." (Page 22). Recent studies have suggested that under conditions of high uncertainty managers may be more inclined to use heuristics (Bingham and Haleblian, 2012; Davis, Eisenhardt \&, Bingham 2009; Easterby-Smith, Lyles, and Peteraf, 2009; Eisenhardt and Martin, 2000), which are simple rules that focus on capturing opportunities (Bingham et al., 2007). Research on managerial heuristics explain that these simple rules are cognitive categorizations that focus managerial attention to enable dealing quickly with issues (Bingham, Eisenhardt, and Furr, 2007; Daft and Weick, 1984; Friedman, 1979). Bingham and Eisenhardt (2011) suggest that as 'heuristics are 'easy to access and remember,' they are readily communicated and understood by dispersed firm members" (p. 1457). Researchers further argue that heuristics can enable greater responsiveness, flexibility and improvisation (Bingham, et al., 2007; Brown and Eisenhardt, 1997; Miner, Bassoff and Moorman, 2001). Accordingly studies in this stream suggest that heuristics may outperform analytically complicated and information-intensive 
approaches (Gigerenzer, 2008; Gigerenzer and Brighton, 2009; Goldstein and Gigerenzer, 2009; Wilson and Schooler, 1991).

Managers learn these opportunity-capture heuristics based on their understanding of the context and re-evaluate and modify them based on their experience. Bingham and Eisenhardt (2011) explain that "firms engage in simplification cycling in which they add and prune heuristics" (p. 1458). Our methodology, may simplify the technological landscape by providing an easy way to understand the dynamic environment in which their firm's operates. Using our methodology to form heuristics can help managers address various issues including those that influence the technology evolution of an industry. For example, during paradigm shifts, uncertainty about the technological and commercial success increases (Schilling 1998) and firms are faced with the need to reassess their position. This is also the case during periods of changes to the availability and pricing of the firm's inputs (Ahuja et al 2013). A better understanding of the firm's technological foot print and its competitors' footprints, as well as choices of technological repositioning, may enable more efficient response to such changes. Ahuja et al (2013) examined the impact of a firm's diversification on its technological response to oil prices and found that managers tend to invest in paradigm-changing technologies (substitutional technologies) the greater the relatedness of their business activities and more in paradigm-deepening technologies (cost saving technologies) when their business activities are unrelated. Using our methodology managers not only can better understand their firm's dependency on a specific technological component but also may be able to assess their best repositioning option, even before facing external shocks or paradigm shifts. 
Overall, we suggest that regardless of the methods managers use to help them with their decision making process, complex routines or heuristics, tools that increase the corporate management understanding of the technological landscape, better enables the formulations of objectives, strategies (including alternatives) and the heuristics important for reaching more efficient decisions.

\section{DISCUSSION}

We developed a system of mapping patents in technological space that enabled us to develop novel measures related to technological capabilities. At the patent level, we showed how researchers can use these measures to assess the distance between any two inventions, and identify outlier patents. At the firm level, we showed how researchers can use the measures to assess the diversity of a firm's technological footprint, and how that footprint changes over time. Temporal changes in a firm's trajectory, in turn, can be useful for studies on topics such as organizational learning, responses to environmental shocks, mimetic isomorphism, and more. We also showed how researchers can use the measures to compare the technological footprints of multiple firms, including assessing their technological overlap, proximity, and similarity, enabling researchers to be much more comprehensive and nuanced when assessing technological relatedness. Finally, we showed how the mapping technique can be used to observe the evolution of a technological landscape, which should enable fruitful research on technology s-curves, technology shocks, and technological convergence.

The measures here have a number of advantages. First, they leverage the size, scope, and age of the U.S. Patent and Trademark Office database, which offers a very large amount of data spanning back to 1969 , and a very fine grained disaggregation of technology components. We 
suggest, similar to Benner and Waldfogel (2008), that it is essential to use all the classification information on the patent and not just the first classification (which is widely used, as it is the only one available in the NBER data). Further, we show the advantages of creating much more nuanced and precise measures of technological distance, technology footprints, etc. by going down to the level of the main subclass (which enables the researcher to create a vector with nearly 10,000 dimensions), rather than using only the 473 patent classes.

By using the subclasses to create technology positions, rather than treating each subclass as independent, our measures account for the interdependencies between technological components and capabilities. Some subclasses nearly always appear together, suggesting that they should not be considered wholly separate components. Other subclasses are reused with a wide range of other subclasses, or may appear alone, suggesting that they are relatively independent. Approaches that are based, for example, on counts of overlapping classes or subclasses miss this distinction.

Our network measures of technological distance based on adjacency of technology positions provides an empirically-derived measure of technological distance that does not require making any assumptions about how "near" or "far" two subclasses are from one another. This is an important advantage as nearly every taxonomic system for classifying innovations or industries (USPTO classes, WIPO international patent classes, the North American Industrial Classification system, etc.) is criticized for being somewhat ad hoc in its categorization scheme, and it is difficult to justify that the numbering systems used for identifying categories represent any type 
of nominal or ordinal distance. It is thus preferable to create a distance measure based on demonstrated interdependence of activities (Schoen et al, 2012).

An interesting advantage of this type of distance measure (and network maps made using this approach) is that they can provide visual insight into the technology landscape that may otherwise be unknown to both managers and researchers. Network maps can help managers better understand the position they are in or are trying to occupy, reveal neighbors and competitors they may have overlooked, and illuminate technological opportunities they might have otherwise missed. Researchers can use such maps to better understand the boundaries of technology domains and their interdependencies, to better define technology capabilities, and to gain deeper insight into the structure of organizational fields.

We demonstrated the power of these measures both through examples within each section, and through a comparison with traditional measures, as applied to the merger of Continuum Photonics and Polatis Limited. This application indicated that the measures here were likely to be both more reliable, and more precise than more typically used measures of technological diversity and relatedness. Furthermore, these measures do not constrain the researcher to looking only at publicly-held firms. Lastly, all of our measures are based on freely accessible data from the USPTO and thus can be replicated and validated by other researchers.

While we developed our measures with researchers primarily in mind, as we have outlined the measures could also be very useful to managers and policy makers. First, using such measures could help managers get a more in-depth understanding of where their technological strengths 
and weaknesses are, and where they are exposed to competitive threats by other companies who have capabilities superior to their own. The map of the technological landscape should also provide significant insight into where the firm is positioned, what capabilities would be necessary to move into other positions, and where there are relatively unexplored areas of technological terrain. Aligned with studies of the behavioral theory of the firm (e.g. Cyert and March 1963; Bromiley and Washburn, 2011) managers can use the methodology we have suggested to formulate the firms objectives, strategic technological trajectory, and potential alternative strategies. Using this methodology can also lead to the creation of heuristics, and as suggested by Bingham and Eisenhardt (2011), experienced managers may be able to go beyond the creation of low level heuristics (selection and process heuristic) to formulize high level heuristics (temporal and priority heuristics) and to enhance the effectiveness of their decision making process.

Our methodology and proposed measures may also be useful to policy makers. Policy makers can use the technology maps to identify areas in which investment may disproportionately payoff. This can help them to make more astute decisions about programs such as SBIR or NIH grants, the development of incubators and research parks, and the fostering of research consortia. Policy makers can also invest in programs that help develop research and training within universities to complement the industry knowledge within their locations, or the future technological positions they wish to see further developed.

Studies of organizational knowledge, especially those that address issues of organizational learning suggest that congruently with organizational learning there is also "organizational 
forgetting" (Argote \& Epple, 1990; de Holan \& Phillips, 2004). Thus, such studies suggest that knowledge stocks should be discounted as older knowledge entails lower impact on the organization's continued activity and future performance. This may also be in line with the recent decision making studies that emphasize the managerial use of heuristics in complex environments. It may be the case that managers put more emphasis on their more recent knowledge activity and that of their competitors, when planning their firm's future technological trajectory. However, when formulating strategic decisions, managers are able access the entire USPTO database which is available for searching at any point in time, and later art is linked to earlier art through prior art citations. Whereas much of the knowledge stock of an organization may not be codified, the USPTO is explicitly a codification system for efficiently storing and preventing loss or degradation of knowledge. While in our examples we did not discount older knowledge, our measures can be used as aggregated stocks as well as discounted aggregations. This does, however, raise interesting questions. For example if a firm invented knowledge before the discounted time frame, would it not be able to reuse this knowledge again if the market becomes more attractive at a later point? Or would this knowledge become so obsolete that any knowledge the firm needs to develop now would entail new explorations as if the firm had no knowledge in that field? Kodak is one such example, having applied in 1977 for a patent in digital cameras though it did not enter the market until the turn of the century. We believe that future work can explore the diverse issues stemming from discounted stocks and assess questions such as: under which conditions would it be better for managers to use discounted stocks? what is the optimal discounted time frame? and what is the most efficient way to discount? 
The mean number of classes per patents that we looked at is 3.4. Studies on knowledge recombination literature, such as Sorenson, Rivkin, \& Fleming, (2006), explain that the classes assigned to a patent entail interdependencies between the different components. The more classes the patent is classified to the more interdependencies need to be addressed to create new innovations in that location, requiring greater knowledge of the components and their interdependencies from the inventors and firms in that location. Thus, the number of classifications of the patent can be related to the complexity of the invention. However, it could be the case that some components are often recombined with others. This may suggest, on the one hand, that these components may be in closer proximity to each other than others or that more knowledge is available on the particular combination making it easier to utilize the combination in the innovation process. Future research may be able to explore the notion of distances within distances of the technological positions, assessing their existence and their merits.

It must be noted, however, that these measures also impose some limitations. First, our measures are based on patent data, and thus are only useful for assessing firms for whom patents are a reliable indicator of their technological capabilities and activity. Though many sectors of the economy make vigorous use of patents (e.g., electronics, computers, hardware, software, medical equipment drugs, chemicals, and others), there are other sectors that make little use of patents, including many services, agriculture, retail, and more. Second, our measures have been developed with the USPC system, the oldest patent classification system in the world, in mind. Their generalizability to other patent classification systems will depend on a) the granularity of the patent classification system, and b) the degree to which the system has a technological 
orientation. We have already discussed some of the key differences between the USPC and IPC systems; even more differences may arise when we consider patent classification systems such as the European Classification (ECLA) system or the File Index (FI) and File-Forming Term (Fterm) systems of Japan. Globally, the patent offices of the world are working to create a harmonized, fine-grained system called the Cooperative Patent Classification (CPC) system, and we believe our method will work well with this system.

A third limitation of our study is that we have chosen to use the mainline subclasses to create the vectors used here; arguably, one could create even finer-grained measures by looking at the lowest level subclasses (though at a cost of having much longer vectors and many more technology positions to handle, which creates a large data storage and computational burden). In addition, and related to the last point, even when using only the mainline subclasses, the method used here can be difficult - storing, manipulating, and calculating network distances with a database of more than eight million patents creates non-trivial challenges. We have addressed this last limitation by developing an interface that will permit researchers to access our annually updated database, and obtain most of the measures used here. It is our hope that researchers will be able to use the data and measures developed here to fruitfully explore issues such as technology capabilities, technology evolution, innovation, diversification, and more.

Another limitation is relates to the managerial decision making. While we suggest that managers may be able to use our methodology and measures to gather information that can be helpful in their decision making and potential even formulize heuristics, until tested it remains a theoretical argument. Further it is plausible that bounded-rational managers with access to limited 
organizational memory and limited predictive foresight use a only a more basic set of heuristics or simplifying rules to make rough estimates of the breadth and depth of the technological footprint and the degree of technological overlap, similarity, and proximity (Bingham \& Eisenhardt, 2011; Bingham, Eisenhardt, \& Furr, 2007; Bingham \& Haleblian, 2012). Thus, managers may choose not to utilize what we have suggested and to make their strategic decisions about future technology development and investments using a greatly simplified set of using other measures and information gathered via their own experience about their own firm's and other firms' patent portfolios.

Finally, as we have not compared empirically our measures to the citation-based measures, we are not able to provide information elaborating when it is better to use one over the other. In this regards it is important to note that the citation processes provides information on the lineage of the patent (Mowery et al, 1996, 1998). As Mowery et al (1996, p.83) explain that citations of prior patents "serve as an indicator of the technological lineage of new patents, much as bibliographic citations indicate the intellectual lineage of academic research. The citation process was not designed to represent a taxonomy (Alcacer \& Gittelman, 2006; Benner \& Waldfogel, 2008). Citations were shown to serve as a good proxy for the value of the patented innovation (Harhoff, et. al., 1999; Hall, Jaffe, and Trajtenberg, 2001; McGahan and Silverman, 2006). The classification system, on the other hand, is designed to represent taxonomy and increase the efficiency of search, underscoring the technological components composition of the innovation (Jaffe 1986). We hope that future research can provide empirically evidence to illuminate this issue, examining the different managerial decisions within the technological landscape and 
assessing under which circumstances using classification based measure would be more beneficial than citation based measures. 


\section{REFERENCES}

Ahuja, G. and Katila, R. 2001. The duality of collaboration: inducements and opportunities in the formation of interfirm linkages. Strategic Management Journal, 22:197-220.

Ahuja, G. and Katila, R. 2004. Where do resources come from? The role of idiosyncratic situations. Strategic Management Journal, 25:887-907.

Ahuja, Gautam, Curba Morris Lampert, and Vivek Tandon. 2013. "Paradigm-Changing vs. Paradigm-Deepening Innovation: How Firm Scope Influences Firm Technological Response to Shocks." Organization Science 25(3): 653-669.

Alcacer, J. and Gittelman, M. 2006. Patent citations as a measure of knowledge flow: The influence of examiner citations. Review of Economics and Statistics, 88:774-779.

Almeida, P. and Kogut, B. 1999. Localization of knowledge and the mobility of engineers in regional networks. Management Science, 45:905-917.

Almeida, P., Dokko, G. and Rosenkopf, L. 2003. Startup size and the mechanisms of external learning: Increasing opportunity and decreasing ability? Research Policy 32: 301-315.

Anderson, P and Tushman, ML. 1990. Technological discontinuities and dominant designs: A cyclical model of technological change. Administrative Science Quarterly, 35:604-633.

Argote L., and Epple, 1990. Learning Curves in Manufacturing. Science. 247: 920-924

Audretsch, D.B. and Feldman, M.P. 1996. R\&D spillovers and the geography of innovation and production. American Economic Review 86: 630-640.

Ayres, R.U. 1994. Toward a non-linear dynamics of technological progress. Journal of Economic Behavior and Organization, 24:35-69.

Barr, T and Leiponen, A. 2012. A measure of technological distance. Economics Letters, 116:457-459. 
Benner, M. \& Waldfogel, J. 2008. Close to you? Bias and precision in patent-based measures of technological proximity. Research Policy, 37:1556-1567.

Bingham, C.B. and Eisenhardt, K.M. 2011. Rational heuristics: the 'simple rules' that strategists learn from process experience. Strategic Management Journal, 32(13): 1437-1464.

Bingham, C.B. and Haleblian, J.J. 2012. How firms learn heuristics: Uncovering missing components of organizational learning. Strategic Entrepreneurship Journal, 6(2): 152-177.

Bingham, C.B., Eisenhardt, K.M., and Furr, N. R. 2007. What makes a process a capability? Heuristics, strategy, and effective capture of opportunities. Strategic Entrepreneurship Journal, 1(1-2): 27-47.

Bromiley, P., and Washburn. M. 2011 "Cost reduction vs innovative search in R\&D." Journal of Strategy and Management 4(3): 196-214.

Brown S.L., and Eisenhardt K.M. 1997. The art of continuous change: linking complexity theory and time-paced evolution in relentlessly shifting organizations. Administrative Science Quarterly 42(1): 1-34.

Carter, E. E. 1971. 'The behavioral theory of the firm and top-level corporate decisions', Administrative Science Quarterly, 16: 413-428.

Chen, W. and Miller, K.D. 2007, “Situational and institutional determinants of firms' R\&D search intensity", Strategic Management Journal, 28(4): 369-81.

Christensen, C.M. 1993. The rigid disk drive industry: A history of commercial and technological turbulence. Business History Review, 67:531-588.

Christensen, C.M. 1994. Exploring the limits of the technology s-curve. Production and Operations Management. 1(4):334-366. 
Chung, W. and Alcacer J. 2002. Knowledge seeking and location choice of foreign direct investment in the United States. Management Science, 12: 1534-1554.

Cohen W.M. and Levinthal, D.A. 1990. Absorptive Capacity: A New Perspective on Learning and Innovation. Administrative Science Quarterly. 35(1): 128-152

Cyert, R.M. \& March, J.G. 1963. A behavioral theory of the firm. Englewood Cliffs, NJ: Prentice-Hall.

Daft R.L, Weick K.E. 1984. Toward a model of organizations as interpretation systems. Academy of Management Review 9(2): 284-295.

Davis J.P., Eisenhardt K.M., and Bingham C.B. 2009. Optimal Structure, Market Dynamism, and the Strategy of Simple Rules." Administrative Science Quarterly, 54: 413-452.

De Holan P.M. and Phillips, 2004. Remembrance of things past? The dynamics of organizational forgetting. Management Science 50(11): 1603-1613

Diestre, L and Rajagopalan, N. 2012. Are all 'sharks' dangerous? New biotechnology ventures and partner selection in R\&D alliances. Strategic Management Journal, 33:1115-1134.

Dosi G. 1988. The Nature of the Innovative Process. In: Technical Change and Economic Theory (eds. Dosi G, Freeman C, Nelson R, Silverberg G \& Soete L). Pinter Publishers, London

Dushnitsky, G and Lenox, MJ. 2005. When do incumbents learn from entrepreneurial ventures? Corporate venture capital and investing firm innovation rates. Research Policy, 34:615639.

Easterby-Smith M, Lyles MA, Peteraf M. 2009. Dynamic capabilities: current debates and future directions. British Journal of Management 20(1): 1-8. 
Eisenhardt K.M. 1989. Making fast strategic decisions in highvelocity environments. Academy of Management Journal 32(3): 543-576.

Eisenhardt K.M. and Martin J.A. 2000. Dynamic capabilities: what are they? Strategic Management Journal. 21(10/11): 1105-1121.

Eisenhardt K.M. and Zbaracki M.J. 1992. Strategic decision making. Strategic Management Journal. Volume 13, Issue S2, pages 17-37, Winter 1992

Feldman, M.P. 1994. The Geography of Innovation. Dordrecht: Kluwer Academic Publishers. Feldman, M. P. 2003. The locational dynamics of the U.S. biotech industry: Knowledge externalities and the anchor hypothesis. Industry and Innovation, 10: 311-328.

Fleming, L. 2001. Recombinant uncertainty in technological search. Management Science, 47: 117-132

Fleming, L., and Sorenson, O. 2001. Technology as a complex adaptive system: Evidence from patent data. Research Policy 30: 1019-1940

Fleming, L., and Sorenson, O. 2004. Science as a map in technological search. Strategic Management Journal, 25:909-928.

Foster, R. N. 1986. Innovation: The attacker's advantage. NY: Summit Books.

Friedman A. 1979. Framing pictures: The role of knowledge in automatized encoding and memory for gist. Journal of Experimental Psychology 108: 316- 355.

Gerken, J.M., and Moehrle, M.G. 2012. A new instrument for technology monitoring: novelty in patents measured by semantic patent analysis. Scientometrics, 91:645-670.

Gigerenzer, G. 2008. Why heuristics work. Perspectives on Psychological Science 3(1): 20-29. Gigerenzer, G., and Brighton H. 2009. Homo heuristicus: why biased minds make better inferences. Topics in Cognitive Science 1(1): 107-143. 
Gilfillan, S.C. 1935. The Sociology of Invention. Chicago: Follett.

Gilsing, V., Nooteboom, B., Vanhaverbeke, W, Duysters, G. and van den Oord, A. 2008. Network embeddedness and the exploration of novel technologies: Technological distance, betweenness centrality and density. Research Policy, 37:1717-1731.

Goldstein, D.G., and Gigerenzer, G. 2009. Fast and frugal forecasting. International Journal of Forecasting 25: 760-772.

Gomes-Casseres, Benjamin, John Hagedoorn, and Adam B. Jaffe. 2006 "Do alliances promote knowledge flows?." Journal of Financial Economics 80(1): 5-33.

Hall, B.H., Jaffe A., and Trajtenberg M. 2001. "The patent paradox revisited: An empirical study of patenting in the US semiconductor Industry, 1979-95. RAND Journal of Economics, 32: $101-128$

Hall, B.H., and Ziedonis, R.H. 2001. The patent paradox revisited: an empirical study of patenting in the US semiconductor industry, 1979-1995. RAND Journal of Economics, $32: 101-128$

Harhoff, D., Narin, F., Scherer, F.M., and Vopel, K. 1999. Citation frequency and the value of patented innovations. Review of Economics and Statistics, 81: 511-515.

Harlow, H. F. 1959 "Learning set and error factor theory." In S. Koch (ed.), Psychology: A Study of Science, 2: 492-537. New York: McGraw-Hill.

Harris, CG, Arens, R, \& Srinivasan, P. 2010. Comparison of the IPC and USPC classification system in patent prior art searches. Proceedings of the $3^{\text {rd }}$ International Workshop on Patent Information Retrieval, Association for Computing Machinery, 27-32.

Henderson, R. 1994. The evolution of integrative capability: Innovation in cardiovascular drug discovery. Industrial and Corporate Change, 3:607-630. 
Henderson, R. and Clark, K. 1990. Architectural innovation: The reconfiguration of existing product technologies and the failure of established firms. Administrative Science Quarterly, 35: 9-30.

Holland, J. 1975. Adaptation in natural and artificial systems. U. of Michigan Press, Ann Arbor, MI.

Iyer, D.N. and Miller, K.D. 2008. Performance feedback, slack, and the timing of acquisitions. Academy of Management Journal, 51(4): 808-22.

Jaffe, A.B., 1986. Technological opportunity and spillovers of R\&D: Evidence from firms’ patents, profits and market value. American Economic Review. 76: 984-1001.

Jaffe, A.B. 1989. Demand and supply influences in R \& D intensity and productivity growth. The Review of Economics and Statistics, 70: 431-437.

Jaffe, A.B., Trajtenberg, M., and Henderson, R. 1993. Geographic localization of knowledge spillovers as evidenced by patent citations. Quarterly Journal of Economics 108: 577-98.

Kapoor, R. and Lim, K. 2007. The impact of acquisitions on the productivity of inventors at semiconductor firms: A synthesis of knowledge-based and incentive-based perspectives. Academy of Management Journal, 50:1133-1155.

Kauffman, S.A., Lobo, J. \& Macready, W.G. 2000. Optimal search on a technology landscape. Journal of Economic Behavior \& Organization, 43:141-166.

Kim,D. and Kogut, B. 1996. Technological Platforms and Diversification. Organization Science, 7(3): 283-301.

Koestler, A. 1964. The act of creation. New York: Dell. 
Kotha, R., Zheng, Y. and George, G. 2011. Entry into new niches: The effects of firm age adn the expansion of technological capabilities on innovative output and impact. Strategic Management Journal, 32:1011-1024.

Lerner J., 1994. The importance of patent scope: an empirical analysis. The RAND Journal of Economics. 25: 319-333.

Lerner J., 1995. Patenting in the shadow of competitors. Journal of Law and Economics 38 (October 1995): 563-95.

March, J. G. 1991. Exploration and exploitation in organizational learning. Organization Science 2: 71-87.

McGahan, A.M. and Silverman, B.S. 2006. Profiting from Others' Technological Innovation: The Effect of Competitor Patenting on Firm Value. Research Policy, 35(8): 1222-1242

Miner AS, Bassoff, P., and Moorman C. 2001. Organizational improvisation and learning: a field study. Administrative Science Quarterly 46: 304-337.

Mitchell, M. 1996. An Introduction to Genetic Algorithms. MIT Press,Cambridge, MA.

Moehrle, M.G. 2010. Measures for textual patent similarities: A guided way to select appropriate approaches. Scientometrics: 85:95-109.

Mowery D.C., Oxley JE, Silverman BS. 1996. Strategic alliances and interfirm knowledge transfer. Strategic Management Journal, Winter Special Issue 17: 77-91.

Mowery D.C., Oxley JE, and Silverman BS. 1998. Technological overlap and interfirm cooperation: implications for the resource-based view of the firm. Research Policy 27: 507-523.

Nelson, R.R. and Winter, S. 1982. An Evolutionary Theory of Economic Change. Cambridge, MA: Harvard University Press. 
Penrose, E.T. 1959. The theory of the growth of the firm. New York: John Wiley.

Podolny, Joel M. and Toby E Stuart. 1995. A Role -Based Ecology of Technological Change. American Journal of Sociology 5:1224-60.

Podolny JM, Stuart TE, and Hannan MT. 1996. Networks, knowledge, and niches: Competition in the worldwide semiconductor industry, 1984-1991. American journal of sociology, 659689

Rosenkopf, L. and Almeida, P. 2003. Overcoming local search through alliances and mobility. Management Science, 49: 751-766.

Rothaermel F.T. and Boeker W. 2008. Old technology meets new technology: complementarities, similarities, and alliance formation. Strategic Management Journal. 29: $47-77$

Sampson, R.C. 2007 "R\&D alliances and firm performance: The impact of technological diversity and alliance organization on innovation." Academy of Management Journal 50(2): 364-386.

Schilling, MA. 1998. Technological lock out: An integrative model of the economic and strategic factors driving technology success and failure. Academy of Management Review, 23:267284.

Schilling, M.A. and Green, E. 2011. Recombinant search and breakthrough idea generation: An analysis of high impact papers in the social sciences. Research Policy, 40: 1321-1331

Schoen, A, Villard, L, Laurens, P, Cointet, P, Heimeriks, G, Alkemade, F. 2012. The network structure of technological developments: Technological distance as a walk on the technology map. Proceedings of the Conference on Science and Technology Indicators, Montreal. 
Schumpeter, J. A. 1934. The theory of economic development. New Brunswick, NP Transaction Publishers

Sears, J. and Hoetker, G. 2013. Technological overlap, technological capabilities, and resource recombination in technological acquisitions. Strategic Management Journal, 35(1):48-67.

Silverman, B.S. 2002. Technological Resources and the Logic of Corporate Diversification, London, UK: Routledge

Sorenson, O., and Fleming, L. 2004. Science and the diffusion of knowledge. Research policy 33 (10), 1615-1634.

Sorenson, O., Rivkin, J.W. and Fleming, L. 2006. Complexity, networks and knowledge flow. Research Policy, 35:994-1017.

Stuart T.E. and Podolny J.M., 1996; Local search and the evolution of technological capabilities. Strategic Management Journal 17(1): 21-38

Teece, DJ, Rumelt, R, Dosi, G, and Winter, S. 1994. Understanding corporate coherence: Theory and evidence. Journal of Economic Behavior and Organization, 23:1-30.

Thompson, P and Kean, MF. 2005. Patent citations and the geography of knowledge spillovers: A reassessment. American Economic Review, 95:450-460.

Twiss, B.C. 1992. Forecasting for technologists and engineers: A practical guide for better decisions. IEE Management of Technology Series 15. London: Peter Peregrinus.

Usher, A. 1954. A History of Mechanical Inventions. Cambridge, MA: Harvard University Press. Von Graevenitz, G, Wagner, S, \& Harhoff, D. 2013. Incidence and growth of patent thickets: The impact of technological opportunities and complexity. Journal of Industrial Economics, 61:521-563. 
Wilson T.D., and Schooler J.W. 1991. Thinking too much: introspection can reduce the quality of preferences and decisions. Journal of Personality and Social Psychology 60(2): 181192.

Winter S. 2003. Understanding dynamic capabilities. Strategic Management Journal 24(10): 991-995.

Wiseman, R.M. and Bromiley, P. 1996. Toward a model of risk in declining organizations: an empirical examination of risk, performance and decline. Organization Science, 7(5): 52443.

Yoon, B., and Park, Y. 2005. A systematic approach for identifying technology opportunities: Keyword-based morphology analysis. Technological Forecasting and Social Change, 72: 145-160.

Yoon, J., and Kim, K. 2012. Detecting signals of new technological opportunities using semantic patent analysis and outlier detection. Scientometrics, 90:445-461.

Yoon, J., Park, H., \& Kim, K. 2013. Identifying technological competition trends for R\&D planning using dynamic patent maps: SAO-based content analysis. Scientometrics, 94(1): 313-331.

Ziedonis, R.H. 2004. Don't fence me in: Fragmented markets for technology and the patent acquisitions strategies of firms. Management Science, 50:804-820.

Zollo M, and Winter S. 2002. Deliberate learning and the evolution of dynamic capabilities. Organization Science 13(3): 339-351. 
Table 1: Path lengths between Technology Positions for a Set of Patents

\begin{tabular}{|c|c|c|c|c|c|c|c|c|c|c|}
\hline & $\begin{array}{l}\text { Micro- } \\
\text { processor } \\
\text { ("Single } \\
\text { chip MOS } \\
\text { computer } \\
\text { with } \\
\text { expandable } \\
\text { memory" }\end{array}$ & $\begin{array}{l}\text { Hard Disk } \\
\text { Drive } \\
\text { ("Updating } \\
\text { and reading } \\
\text { data and parity } \\
\text { blocks in a } \\
\text { shared disk } \\
\text { system") }\end{array}$ & $\begin{array}{l}\text { RAM/ } \\
\text { ROM } \\
\text { ("Hybrid } \\
\text { memory } \\
\text { architectur } \\
\text { e") }\end{array}$ & $\begin{array}{l}\text { Computer } \\
\text { Mouse } \\
\text { ("Cursor } \\
\text { position } \\
\text { device") }\end{array}$ & $\begin{array}{l}\text { Liquid } \\
\text { Crystal } \\
\text { Display }\end{array}$ & $\begin{array}{l}\text { Medical } \\
\text { Device } \\
\text { ("Apparatu } \\
\text { s for } \\
\text { delivery of } \\
\text { multiple } \\
\text { distributed } \\
\text { stents") }\end{array}$ & $\begin{array}{l}\text { Medical } \\
\text { Device } \\
\text { ("Dispos } \\
\text { able } \\
\text { infusion } \\
\text { device") }\end{array}$ & $\begin{array}{l}\text { Medical } \\
\text { Device } \\
\text { ("Systems for } \\
\text { applying a } \\
\text { suture within a } \\
\text { blood vesel } \\
\text { lumen") }\end{array}$ & $\begin{array}{l}\text { Biotech } \\
\text { Method } \\
\text { ("Process for } \\
\text { producing } \\
\text { biologically } \\
\text { functional } \\
\text { molecular } \\
\text { chimeras) }\end{array}$ & $\begin{array}{l}\text { Hybrid } \\
\text { Corn } \\
\text { ("Hybrid } \\
\text { corn plant } \\
\text { and seed") }\end{array}$ \\
\hline & Intel & IBM & $\begin{array}{l}\text { Dallas } \\
\text { Semicondu } \\
\text { ctor }\end{array}$ & Xerox & Sharp & Xtent & Insulet & $\begin{array}{l}\text { Aptus } \\
\text { Endosystems }\end{array}$ & $\begin{array}{l}\text { Stanley Cohen } \\
\text { \& Herbert } \\
\text { Boyer }\end{array}$ & $\begin{array}{l}\text { Pioneer } \\
\text { Hi-Bred } \\
\text { Internatio } \\
\text { nal }\end{array}$ \\
\hline Patent \# & 4153933 & 6446237 & 4995004 & 3987685 & 5467208 & 7137993 & 6485461 & 6800081 & 4237224 & 4731499 \\
\hline $\begin{array}{l}\text { Date } \\
\text { granted }\end{array}$ & 08-May-79 & 03-Sep-02 & 19-Feb-91 & 26-Oct-76 & 14-Nov-95 & 21-Nov-06 & $\begin{array}{l}26-\text { Nov- } \\
02\end{array}$ & $05-$ Oct-04 & 02-Dec-80 & 15-Mar-88 \\
\hline $\begin{array}{l}\text { Position } \\
\text { Location }\end{array}$ & 1867829 & 1869589 & 1642232 & 547319 & 1599348 & 1849291 & 1848808 & 1849077 & 1805969 & 275822 \\
\hline 1867829 & & 4 & 3 & 6 & 8 & 7 & 5 & 5 & 13 & 8 \\
\hline 1869589 & 4 & & 3 & 6 & 8 & 5 & 5 & 5 & 13 & 6 \\
\hline 1642232 & 3 & 3 & & 7 & 7 & 6 & 4 & 4 & 12 & 7 \\
\hline 547319 & 6 & 6 & 7 & & 8 & 7 & 5 & 5 & 15 & 8 \\
\hline 1599348 & 8 & 8 & 7 & 8 & & 7 & 7 & 5 & 15 & 10 \\
\hline 1849291 & 7 & 5 & 6 & 7 & 7 & & 2 & 2 & 10 & 5 \\
\hline 1848808 & 5 & 5 & 4 & 5 & 7 & 2 & & 2 & 10 & 5 \\
\hline 1849077 & 5 & 5 & 4 & 5 & 5 & 2 & 2 & & 10 & 5 \\
\hline 1805969 & 13 & 13 & 12 & 15 & 15 & 10 & 10 & 10 & & 11 \\
\hline 275822 & 8 & 6 & 7 & 8 & 10 & 5 & 5 & 5 & 11 & \\
\hline
\end{tabular}


Table 2: Insulet Technology Footprint

\begin{tabular}{|c|c|c|c|c|c|c|c|c|}
\hline $\begin{array}{r}\text { Mainline } \\
\text { subclasses }\end{array}$ & $\begin{array}{l}\stackrel{8}{\varrho} \\
\stackrel{\infty}{\infty} \\
\text { I }\end{array}$ & 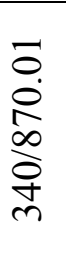 & $\begin{array}{l}\bar{O} \\
\overline{8} \\
\stackrel{8}{0}\end{array}$ & $\begin{array}{l}\stackrel{8}{8} \\
\text { } \\
\stackrel{8}{8} \\
\stackrel{0}{8}\end{array}$ & 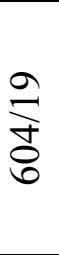 & $\begin{array}{l}\overrightarrow{0} \\
\text { ळे } \\
\infty \\
\text { சீ }\end{array}$ & $\stackrel{\overrightarrow{\hat{\sigma}}}{8}$ & 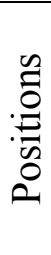 \\
\hline 1. 7303549 & & & & & 1 & & & \multirow[t]{11}{*}{1} \\
\hline 2. 6960192 & & & & & 1 & & & \\
\hline 3. 6692457 & & & & & 1 & & & \\
\hline 4. 6830558 & & & & & 1 & & & \\
\hline 5. 6656159 & & & & & 1 & & & \\
\hline 6. 6656158 & & & & & 1 & & & \\
\hline 7. 7144384 & & & & & 1 & & & \\
\hline 8. 7029455 & & & & & 1 & & & \\
\hline 9. 6723072 & & & & & 1 & & & \\
\hline 10. 6699218 & & & & & 1 & & & \\
\hline 11. 7018360 & & & & & 1 & & & \\
\hline 12. 6669669 & & & & & 1 & 1 & & \multirow[t]{2}{*}{2} \\
\hline 13. 6749587 & & & & & 1 & 1 & & \\
\hline 14. 6768425 & 1 & 1 & & & 1 & 1 & & 3 \\
\hline 15. 6740059 & & & 1 & 1 & 1 & & 1 & 4 \\
\hline 16. 7137964 & & & & 1 & 1 & 1 & & 5 \\
\hline
\end{tabular}


Table 3: Xtent Technology Footprint

\begin{tabular}{|c|c|c|c|c|c|c|}
\hline $\begin{array}{r}\text { Mainline } \\
\text { Subclasses }\end{array}$ & \multirow{2}{*}{$\frac{8}{8}$} & \multirow{2}{*}{ 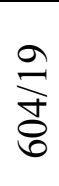 } & \multirow{2}{*}{ ह } & \multirow{2}{*}{ 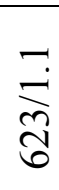 } & \multirow{2}{*}{$\frac{8}{\frac{8}{2}}$} & \multirow{2}{*}{$\begin{array}{l}\mathscr{0} \\
: \frac{0}{\mathscr{D}} \\
0 \\
0\end{array}$} \\
\hline Patents & & & & & & \\
\hline 1. 7326236 & & & & 1 & & 1 \\
\hline 2. 7309350 & & & & 1 & & \\
\hline 3. 7241308 & & & & 1 & & \\
\hline 4. 7182779 & & & & 1 & & \\
\hline 5. 7147656 & & & & 1 & & \\
\hline 6. 7147655 & & & & 1 & & \\
\hline 7. 7320702 & & & & 1 & & \\
\hline 8. 7137993 & & & & 1 & & \\
\hline 9. 7351255 & & & & 1 & & \\
\hline 10.7553324 & & & & 1 & & \\
\hline 11.7294146 & & & & 1 & & \\
\hline 12.7192440 & & & & 1 & & \\
\hline 13.7175653 & & & & 1 & & \\
\hline 14. 7323006 & 1 & & & 1 & & 2 \\
\hline 15.7402168 & & 1 & & 1 & & 3 \\
\hline 16.7300456 & & 1 & & 1 & & \\
\hline 17.7270668 & & & 1 & 1 & & 4 \\
\hline 18.7357812 & & & & 1 & 1 & 5 \\
\hline
\end{tabular}


Table 4: Aptus Endosystems Technology Footprint

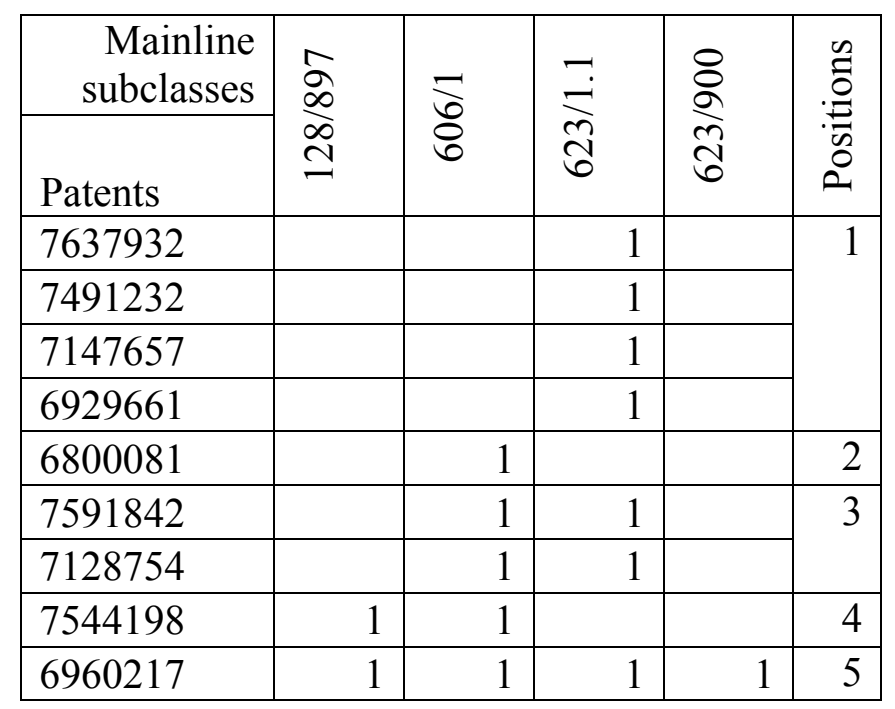


Table 5: Aggregated technology vectors for Aptus Endosystems and Xtent

\begin{tabular}{|c|c|c|c|c|c|c|c|c|c|c|c|}
\hline & 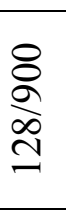 & $\begin{array}{l}\hat{\alpha} \\
\stackrel{\infty}{\infty} \\
\stackrel{D}{(}\end{array}$ & $\begin{array}{l}\overrightarrow{0} \\
\stackrel{\rho}{\infty} \\
\infty \\
\dot{\infty} \\
\dot{d}\end{array}$ & $\begin{array}{l}\stackrel{\overline{0}}{\circ} \\
\stackrel{8}{\delta}\end{array}$ & $\begin{array}{l}\stackrel{8}{0} \\
\text { } \\
\stackrel{8}{8}\end{array}$ & 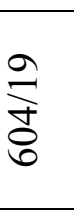 & $\begin{array}{l}\overrightarrow{\dot{\delta}} \\
\dot{\infty} \\
\dot{\delta}\end{array}$ & $\frac{\bar{\delta}}{\grave{0}}$ & $\underset{\widehat{\delta}}{\stackrel{\delta}{8}}$ & 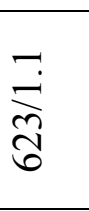 & 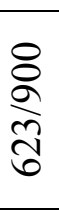 \\
\hline Aptus Endosystems & 0 & 2 & 0 & 0 & 0 & 0 & 0 & 5 & 0 & 7 & 1 \\
\hline Xtent & 0 & 0 & 0 & 0 & 1 & 2 & 0 & 1 & 0 & 18 & 1 \\
\hline Insulet & 1 & 0 & 1 & 1 & 2 & 16 & 4 & 0 & 1 & 0 & 0 \\
\hline
\end{tabular}


Table 6: Summary of Current and Prior Measures (Purpose, Advantages, and Potential Limitations)

\begin{tabular}{|l|l|l|}
\hline Measures & Purpose & Advantages/Disadvantages \\
\hline $\begin{array}{l}\text { Fechnology Distance } \\
\text { (Geodesic distance between } \\
\text { technology positions based } \\
\text { on subclass vectors) }\end{array}$ & $\begin{array}{l}\text { Firm-level } \\
\text { technological } \\
\text { relatedness, proximity; } \\
\text { Field-level } \\
\text { identification of } \\
\text { outliers, etc. }\end{array}$ & $\begin{array}{l}\text { Advantages: } \\
\text { 1. Fine-grained (use of subclasses) enables more precise definition of } \\
\text { technology positions } \\
\text { 2. Empirically derived distance measures based on observed proximities } \\
\text { 3. Can be used to create visual images of the technology landscape } \\
\text { Potential Limitations: } \\
\text { 1. Distance measures based on network algorithms are computationally } \\
\text { intensive. } \\
\text { 2. Decisions must be made about far back to include data for network } \\
\text { distance measures as these statistics change over time due to the addition of } \\
\text { patents in new technology positions. }\end{array}$ \\
\hline $\begin{array}{l}\text { Technological footprint } \\
\text { Aggregation of all } \\
\text { technology positions a firm } \\
\text { is in) }\end{array}$ & $\begin{array}{l}\text { Characterization of a } \\
\text { firm's technology } \\
\text { profile; comparison of } \\
\text { two or more firm } \\
\text { profiles }\end{array}$ & $\begin{array}{l}\text { Advantages: } \\
\text { 1. Footprints can be compared both across rivals and over time to identify } \\
\text { learning trajectories, identify opportunities and threats, etc. } \\
\text { 2. Measure can be easily used within longer or shorter time windows } \\
\text { depending on purposes of researcher. }\end{array}$ \\
\hline $\begin{array}{l}\text { Concentration/Breadth } \\
\text { (Herfindahl Hirschman } \\
\text { Index of shares in } \\
\text { technology positions; for } \\
\text { breadth HHI measure } \\
\text { inverted) }\end{array}$ & $\begin{array}{l}\text { Assessing the breadth } \\
\text { of a firm's technology } \\
\text { portfolio, or its } \\
\text { reliance on a few } \\
\text { technological } \\
\text { capabilities }\end{array}$ & $\begin{array}{l}\text { Advantages: } \\
\text { 1. Straightforward way to calculate a firm's degree of technological focus. }\end{array}$ \\
\hline
\end{tabular}




\begin{tabular}{|c|c|c|}
\hline $\begin{array}{l}\text { Technological Proximity } \\
\text { and Similarity } \\
\text { (1. Average/minimum pair- } \\
\text { wise Euclidian distance } \\
\text { across all of the } \\
\text { technological positions of a } \\
\text { pair of firms } \\
\text { 2. Overlap of technological } \\
\text { positions } \\
\text { 3. Pair-wise correlation } \\
\text { between the firms' vectors) }\end{array}$ & $\begin{array}{l}\text { Assessing inter-firm } \\
\text { technological } \\
\text { relatedness, } \\
\text { similarity, competitive } \\
\text { threat, etc. }\end{array}$ & $\begin{array}{l}\text { Advantages: } \\
\text { 1. Can create a rich and multidimensional assessment of the degree two } \\
\text { which firms are similar or dissimilar } \\
\text { 2. Permits an asymmetric measure of competitive threat (i.e., A may be } \\
\text { threatening to B but B may not be threatening to A) } \\
\text { 3. Can be used over time to assess the degree to which firms' capabilities } \\
\text { are converging or diverging. }\end{array}$ \\
\hline $\begin{array}{l}\text { Exploitation versus } \\
\text { Exploration } \\
\text { (Technology positions that } \\
\text { are new to the firm or new } \\
\text { to the world) }\end{array}$ & $\begin{array}{l}\text { Identification of } \\
\text { outlier patents; } \\
\text { assessment of a firm's } \\
\text { strategy of exploration } \\
\text { and/or exploitation }\end{array}$ & $\begin{array}{l}\text { Advantages: } \\
\text { 1. Can be used to assess the degree of novelty of an innovation. } \\
\text { 2. Enables early identification of new potential technological areas. } \\
\text { 3. Helps identify outlier firms (those who have unusual search strategies or } \\
\text { capabilities) }\end{array}$ \\
\hline $\begin{array}{l}\text { Technology Lifecycles } \\
\text { (Number of patents within a } \\
\text { technology position over } \\
\text { time or number of patents } \\
\text { within adjacent positions } \\
\text { over time) }\end{array}$ & $\begin{array}{l}\text { Observing the growth } \\
\text { of a technology } \\
\text { position and } \\
\text { knowledge spillovers } \\
\text { in its domain }\end{array}$ & $\begin{array}{l}\text { Advantages: } \\
\text { 1. Straightforward to calculate } \\
\text { 2. Can be used to create visual images of technology evolution } \\
\text { 3. Rate of growth and spread provides some indication of impact and/or } \\
\text { ease of knowledge transfer }\end{array}$ \\
\hline
\end{tabular}




\begin{tabular}{|c|c|c|}
\hline $\begin{array}{l}\text { Measures from Other } \\
\text { Papers: }\end{array}$ & & \\
\hline $\begin{array}{l}\text { Overlap in Patent } \\
\text { Citations (e.g Podolny \& } \\
\text { Stuart, 1995; Stuart \& } \\
\text { Podolny, 1996; Podolny, } \\
\text { Stuart and Hannan1996; } \\
\text { Mowery, Oxley, \& } \\
\text { Silverman, 1996, 1998; } \\
\text { Rothaermel and Boeker } \\
\text { 2008) }\end{array}$ & $\begin{array}{l}\text { Used to assess the } \\
\text { similarity or } \\
\text { dissimilarities between } \\
\text { a pair of firms' } \\
\text { technological } \\
\text { portfolios }\end{array}$ & $\begin{array}{l}\text { Advantages: } \\
\text { 1. Once you have the citations of a pair of firms, relatively easy to construct } \\
\text { the measure of overlap } \\
\text { 2. Provides information about similarities and dissimilarities in the } \\
\text { knowledge source between two firms or a group of innovations. } \\
\text { 3. Provides information on the degree to which a pair of firm rely on similar } \\
\text { technology pool. } \\
\text { Potential Limitations: } \\
\text { 1. Use of citations may not provide adequate information about the } \\
\text { technological base of a particular innovation. } \\
\text { 2. Can be biased by sequential interdependence. } \\
\text { 3. Can be biased by strategic motivations of inventor. }\end{array}$ \\
\hline $\begin{array}{l}\text { Count of Overlapping } \\
\text { Patent Classes } \\
\text { (e.g., Ahuja \& Katila, 2001; } \\
\text { Bar, T. \& Leiponen, A. } \\
\text { 2012, Diestre, L. \& } \\
\text { Rajagopalan, N. 2012; } \\
\text { Dushnitsky \& Lenox, 2005) }\end{array}$ & $\begin{array}{l}\text { Intended to capture } \\
\text { proximity or similarity }\end{array}$ & $\begin{array}{l}\text { Advantages: } \\
\text { 1. Easy to construct for a pair of firms } \\
\text { Potential Limitations: } \\
\text { 1. Measure is very coarse; does not take into account interdependencies } \\
\text { between technological components. }\end{array}$ \\
\hline $\begin{array}{l}\text { Technological similarity } \\
\text { based on pair-wise } \\
\text { correlation of patent } \\
\text { classes } \\
\text { (Gilsing, V., Nooteboom, } \\
\text { B., Vanhaverbeke, W., } \\
\text { Duysters, G., \& van den } \\
\text { Oord, A. 2008) }\end{array}$ & $\begin{array}{l}\text { Assesses similarity of } \\
\text { two firm's innovation } \\
\text { portfolios; also used to } \\
\text { view convergence or } \\
\text { divergence over time. }\end{array}$ & $\begin{array}{l}\text { Advantages: } \\
\text { 1. Provides information about a firm's proficiency within a range of } \\
\text { technological components relative to other firms in the sample. } \\
\text { 2. An aggregated use of classes reduces the complexity involved in the } \\
\text { calculation } \\
\text { 3. The use of time windows provides a temporal view of knowledge } \\
\text { Potential Limitations: } \\
\text { 1. If used on classes rather than subclasses, information is coarse } \\
\text { 2. Ignores interdependencies between technology components } \\
\text { 3. Does not provide a measure of whether knowledge is new to the field }\end{array}$ \\
\hline
\end{tabular}




\begin{tabular}{|c|c|c|}
\hline $\begin{array}{l}\text { Technological similarity } \\
\text { based on pair wise angular } \\
\text { separation or uncentered } \\
\text { correlation } \\
\text { of the patent class } \\
\text { distribution vectors of the } \\
\text { two firms } \\
\text { (e.g., Jafe } 1986 \text { \& Gomes- } \\
\text { Casseres, Hagedoorn, and } \\
\text { Jaffe (2006), Sampson. } \\
\text { 2007) }\end{array}$ & $\begin{array}{l}\text { Assesses similarity of } \\
\text { two firm's innovation } \\
\text { portfolios; also used } \\
\text { as a diversity measure } \\
\text { of partner } \\
\text { technological } \\
\text { capabilities }\end{array}$ & $\begin{array}{l}\text { Advantages: } \\
\text { 1. Provides information about the relative degree of proficiency overlap of } \\
\text { two firms within a range of technological components. } \\
\text { 2. An aggregated use of classes reduces the complexity involved in the } \\
\text { calculation } \\
\text { 3. The use of time windows provides a temporal view of knowledge } \\
\text { Potential Limitations: } \\
\text { 1. If used on classes rather than subclasses, information is coarse } \\
\text { 2. Ignores interdependencies between technology components } \\
\text { 3. Does not provide a measure of whether knowledge is new to the field } \\
\text { 4. Harder to calculate for more than a pair of firms. (Sampson (2007), for } \\
\text { example, used an average of paired calculation when there were more than } \\
\text { two firms on the alliance) }\end{array}$ \\
\hline $\begin{array}{l}\text { Technology Distance } \\
\text { Measured as IPC Network } \\
\text { Structure } \\
\text { (e.g., Schoen, A., Villard, } \\
\text { L., Laurens, P., Cointet, J.- } \\
\text { P., Heimeriks, G., \& } \\
\text { Alkemade, F. 2012) }\end{array}$ & $\begin{array}{l}\text { Used to map a } \\
\text { technology landscape }\end{array}$ & $\begin{array}{l}\text { Advantages: } \\
\text { 1. Provides information about the technologies that are used in an industry, } \\
\text { their frequency of use, and interdependencies. } \\
\text { 2. Once you attain the classification information of the patents, relatively } \\
\text { easy to construct for a specific industry or a sample of firms. } \\
\text { Potential Limitations: } \\
\text { 1. IPC codes do not relate well to technological capabilities or components, } \\
\text { and class level is coarse; If the map were to created using USPTO instead of } \\
\text { IPC and increased components - i.e., to about } 10000 \text {-- this measure could } \\
\text { provide both more complete and nuanced information. }\end{array}$ \\
\hline $\begin{array}{l}\text { Technological Distance } \\
\text { and Similarity Measured } \\
\text { through Text Analysis } \\
\text { (e.g., Gerken, J. M. \& } \\
\text { Moehrle, M. G. 2012; } \\
\text { Yoon, J. \& Kim, K. 2012; } \\
\text { Yoon, J., Park, H., \& Kim, } \\
\text { K. 2013) }\end{array}$ & $\begin{array}{l}\text { Used to map the } \\
\text { technological } \\
\text { positions and } \\
\text { differences between } \\
\text { patents. }\end{array}$ & $\begin{array}{l}\text { Advantages: } \\
\text { 1. Can provide rich measures of similarities and differences between } \\
\text { patents. } \\
\text { 2. Is not limited to classes or subclasses that have been predetermined by } \\
\text { USPTO. } \\
\text { Potential Limitations: } \\
\text { 1. Complex to use } \\
\text { 2. Requires researcher to have some domain-specific knowledge }\end{array}$ \\
\hline
\end{tabular}


Table 7: Patents and Mainline Subclass vectors for Continuum Photonics and Polatis Limited

\begin{tabular}{|c|c|c|c|c|c|c|c|c|c|}
\hline Patents & Title, Filing date and Mainline Classes & $\frac{\vec{d}}{\square]}$ & $\stackrel{0}{\stackrel{0}{o}}$ & 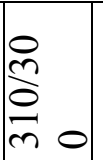 & $\underset{\infty}{\bar{\infty}}$ & $\frac{n}{\infty}$ & $\frac{n}{n}$ & $\begin{array}{l}\stackrel{2}{\infty} \\
\text { ळे }\end{array}$ & $\frac{\stackrel{p}{+}}{\stackrel{\infty}{m}}$ \\
\hline \multicolumn{10}{|l|}{$\begin{array}{l}\text { Continuum } \\
\text { Photonics }\end{array}$} \\
\hline 6995496 & Electrical power extraction from mechanical disturbances & 2000 & & 1 & & & & & \\
\hline 6655035 & Piezoelectric generator & 2001 & & 1 & & & & & \\
\hline 6785437 & Beam-steering optical switching apparatus & 2002 & & & & 1 & 1 & & \\
\hline 6738539 & Beam-steering optical switching apparatus & 2002 & & & & 1 & 1 & & \\
\hline 6975785 & Multiple-axis control system for an optical switch & 2003 & & & & 1 & & & \\
\hline 6909224 & Piezoelectric generator & 2003 & 1 & 1 & & & & & \\
\hline \multicolumn{10}{|l|}{ Polatis Limited } \\
\hline 7106925 & Optical fibre switching assembly & 2001 & & & & 1 & & & \\
\hline 7095915 & Beam steering arrangements and optical switches & 2002 & & & & 1 & & & \\
\hline 7026745 & Piezoelectric actuator & 2002 & & 1 & & & & & \\
\hline 7418167 & Optical switching using optical fiber connector & 2004 & & & & 1 & 1 & & \\
\hline 7389016 & Beam steering optical switch & 2004 & & & & 1 & & & \\
\hline 7324728 & $\begin{array}{l}\text { Optical connector with total internal reflection abutting } \\
\text { surface }\end{array}$ & 2004 & & & & 1 & & & \\
\hline 7105982 & $\begin{array}{l}\text { System for optimal energy harvesting and storage from an } \\
\text { electromechanical transducer }\end{array}$ & 2004 & & 1 & & & & & \\
\hline 7098916 & Beam-steering optical switching apparatus & 2004 & & & & 1 & & & \\
\hline 7680369 & Optical fibre switching assembly & 2005 & & & & 1 & 1 & & \\
\hline 7522789 & Optical switches and actuators & 2005 & & & & 1 & & & \\
\hline 7313295 & $\begin{array}{l}\text { Method and apparatus for variable optical attenuation for an } \\
\text { optical switch }\end{array}$ & 2005 & & & & 1 & & & \\
\hline 7239771 & $\begin{array}{l}\text { Method and system for controlling an optical switch using } \\
\text { dynamic compensation }\end{array}$ & 2005 & & & & 1 & & & \\
\hline 7876981 & Optical switch & 2006 & & & 1 & 1 & & & \\
\hline
\end{tabular}


Mapping the Technological Landscape

\begin{tabular}{|l|l|l|l|l|l|l|l|l|l|}
\hline 8023819 & $\begin{array}{l}\text { Method and apparatus for network fault detection and } \\
\text { protection switching using optical switches with integrated } \\
\text { power detectors }\end{array}$ & 2007 & & & & 1 & 1 \\
\hline 7590316 & Optical switch & 2007 & & & 1 & & & \\
\hline
\end{tabular}


Table 8: Patents and IPC Main Group vectors for Continuum Photonics and Polatis Limited

\begin{tabular}{|c|c|c|c|c|c|c|c|c|c|c|}
\hline Patents & 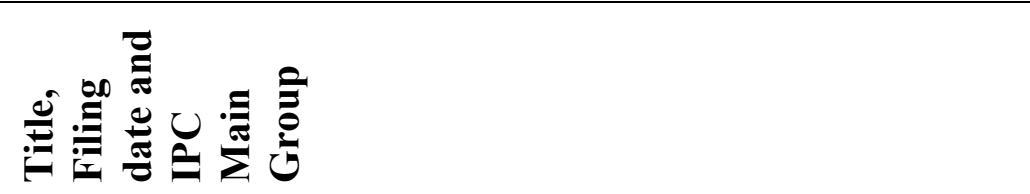 & $\frac{\mathbb{Q}}{i=1}$ & 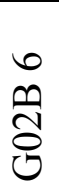 & 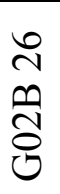 & $\frac{\widetilde{L}}{\widetilde{J}}$ & $\begin{array}{l}a \\
\frac{1}{8} \\
0\end{array}$ & $\underset{6}{-}$ & 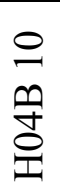 & $\begin{array}{l}\Xi \\
\underset{\Xi}{\Xi} \\
\Xi\end{array}$ & 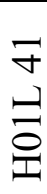 \\
\hline \multicolumn{11}{|c|}{$\begin{array}{l}\text { Continuum } \\
\text { Photonics }\end{array}$} \\
\hline 6995496 & Electrical power extraction from mechanical disturbances & 2000 & & & & & & & & 1 \\
\hline 6655035 & Piezoelectric generator & 2001 & & & & & & & & 1 \\
\hline 6785437 & Beam-steering optical switching apparatus & 2002 & 1 & & & & & & & \\
\hline 6738539 & Beam-steering optical switching apparatus & 2002 & 1 & & & & & & & \\
\hline 6975785 & Multiple-axis control system for an optical switch & 2003 & 1 & & & & & & & \\
\hline 6909224 & Piezoelectric generator & 2003 & & & & & & & & 1 \\
\hline \multicolumn{11}{|c|}{ Polatis Limited } \\
\hline 7106925 & Optical fibre switching assembly & 2001 & 1 & & & & & & & \\
\hline 7095915 & Beam steering arrangements and optical switches & 2002 & 1 & & & & & & & \\
\hline 7026745 & Piezoelectric actuator & 2002 & & & & & & & & 1 \\
\hline 7418167 & Optical switching using optical fiber connector & 2004 & 1 & & & & & & & \\
\hline 7389016 & Beam steering optical switch & 2004 & 1 & & & & & & & \\
\hline 7324728 & $\begin{array}{l}\text { Optical connector with total internal reflection abutting } \\
\text { surface }\end{array}$ & 2004 & 1 & & & & & & & \\
\hline 7105982 & $\begin{array}{l}\text { System for optimal energy harvesting and storage from an } \\
\text { electromechanical transducer }\end{array}$ & 2004 & & & & & & & & 1 \\
\hline 7098916 & Beam-steering optical switching apparatus & 2004 & & & 1 & 1 & 1 & & & \\
\hline 7680369 & Optical fibre switching assembly & 2005 & 1 & & & & & & & \\
\hline 7522789 & Optical switches and actuators & 2005 & 1 & 1 & & & & & & \\
\hline 7313295 & $\begin{array}{l}\text { Method and apparatus for variable optical attenuation for an } \\
\text { optical switch }\end{array}$ & 2005 & 1 & & & & & & & \\
\hline 7239771 & $\begin{array}{l}\text { Method and system for controlling an optical switch using } \\
\text { dynamic compensation }\end{array}$ & 2005 & 1 & & & & & & & \\
\hline 7876981 & Optical switch & 2006 & & & 1 & & & & & \\
\hline
\end{tabular}


Mapping the Technological Landscape

\begin{tabular}{|l|l|l|l|l|l|l|l|l|l|l|}
\hline 8023819 & $\begin{array}{l}\text { Method and apparatus for network fault detection and } \\
\text { protection switching using optical switches with integrated } \\
\text { power detectors }\end{array}$ & 2007 & & & & & 1 & 1 \\
\hline 7590316 & Optical switch & 2007 & 1 & & & & & & & \\
\hline
\end{tabular}


Figure 1: The emergence of technology positions

a) 1979

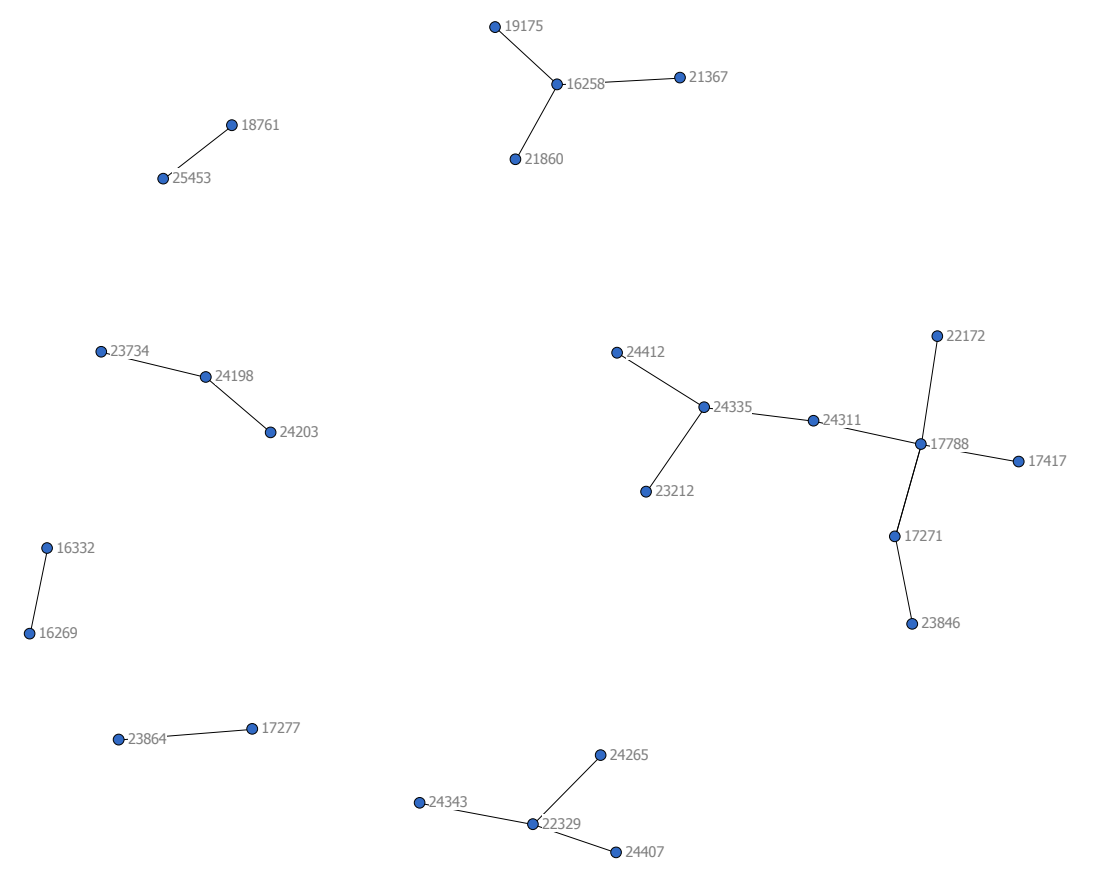

b) 1980

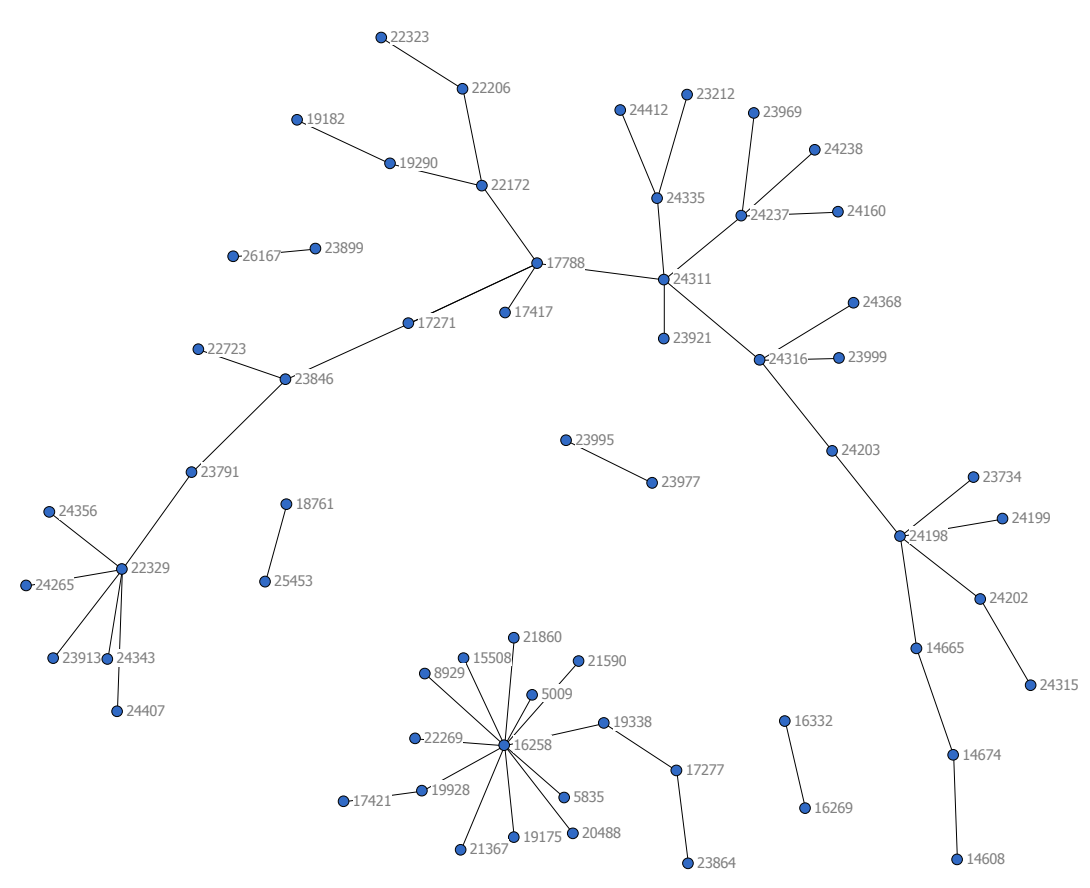


Figure 1: The emergence of technology positions, cont'd

c) 1983

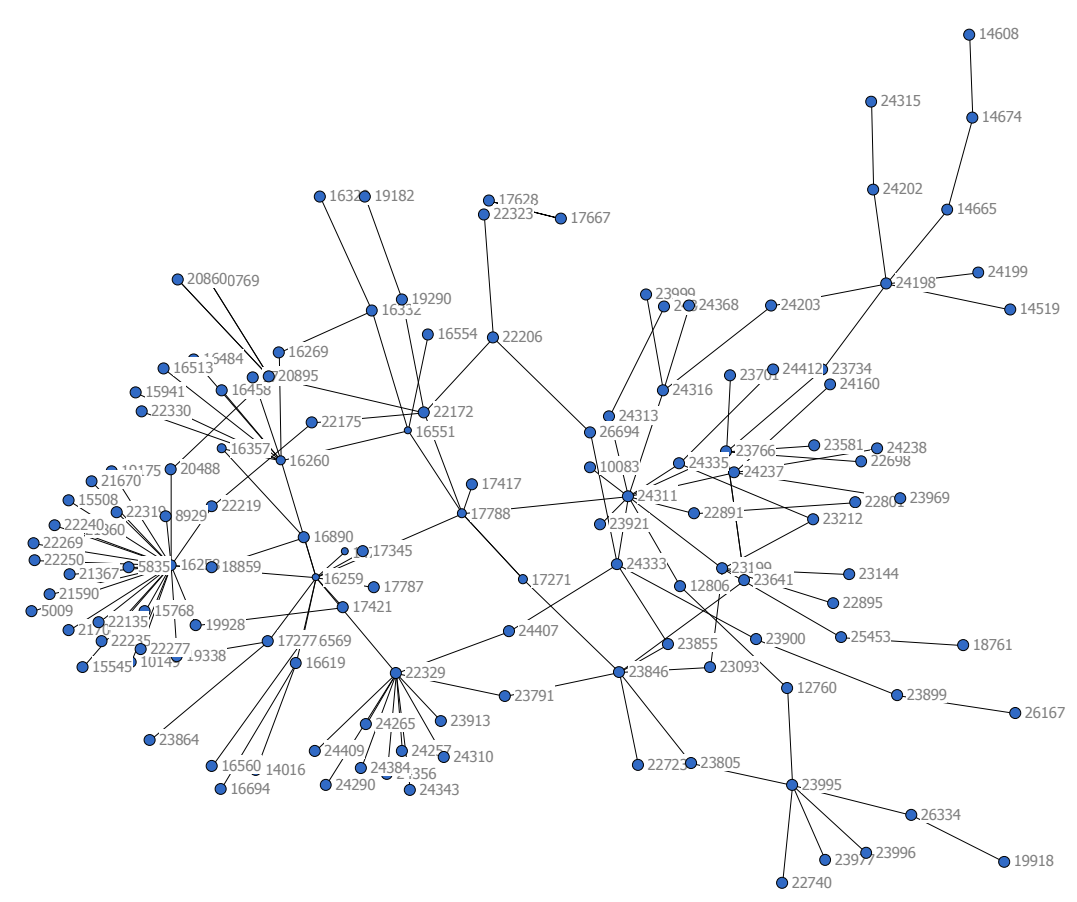

d) 1985

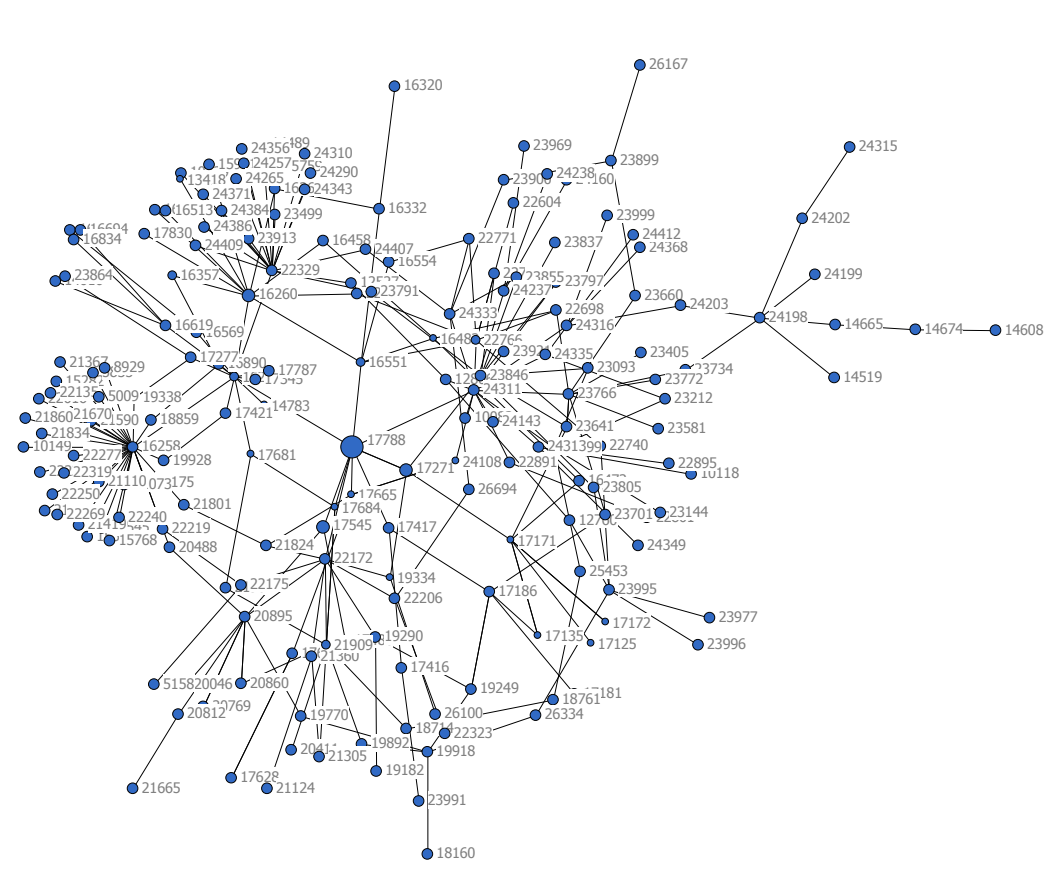


Figure 1: The emergence of technology positions, cont'd

e) 1987

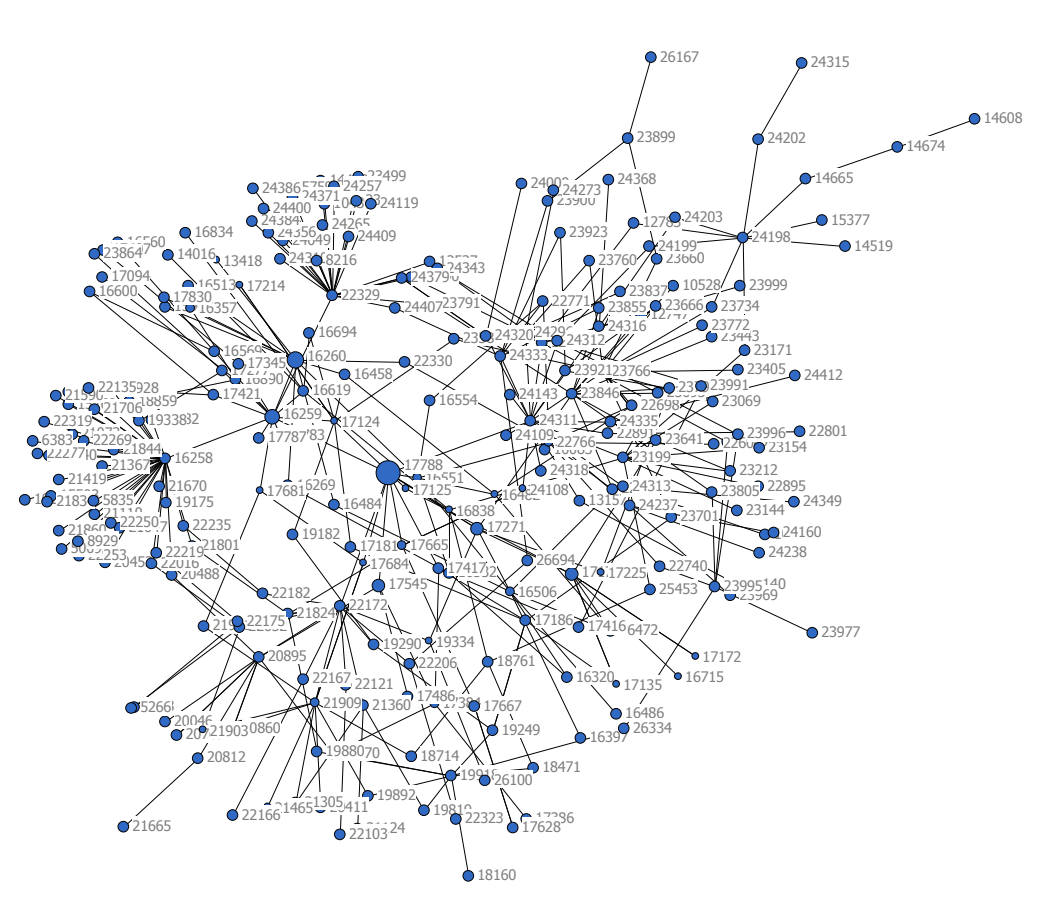

f) 1989

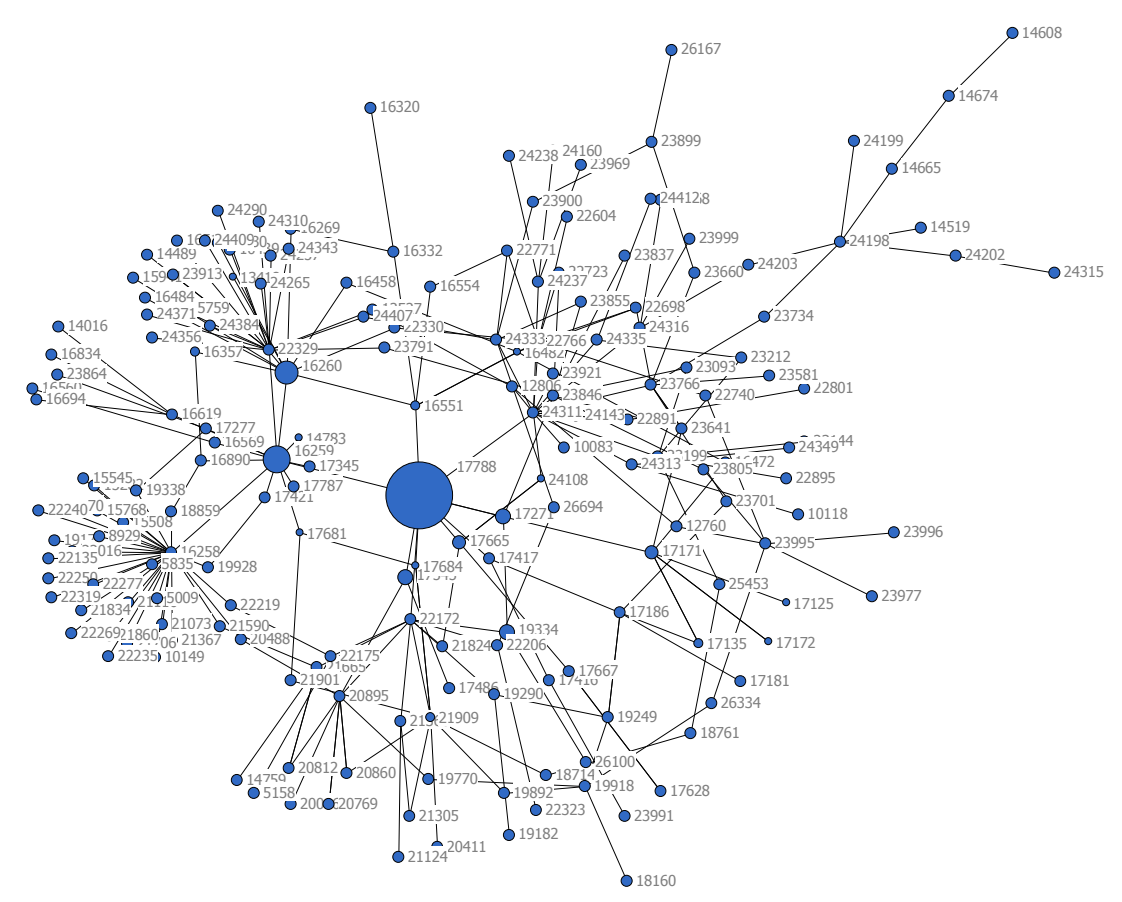


E volution of the $T$ echnological $L$ and sc ape
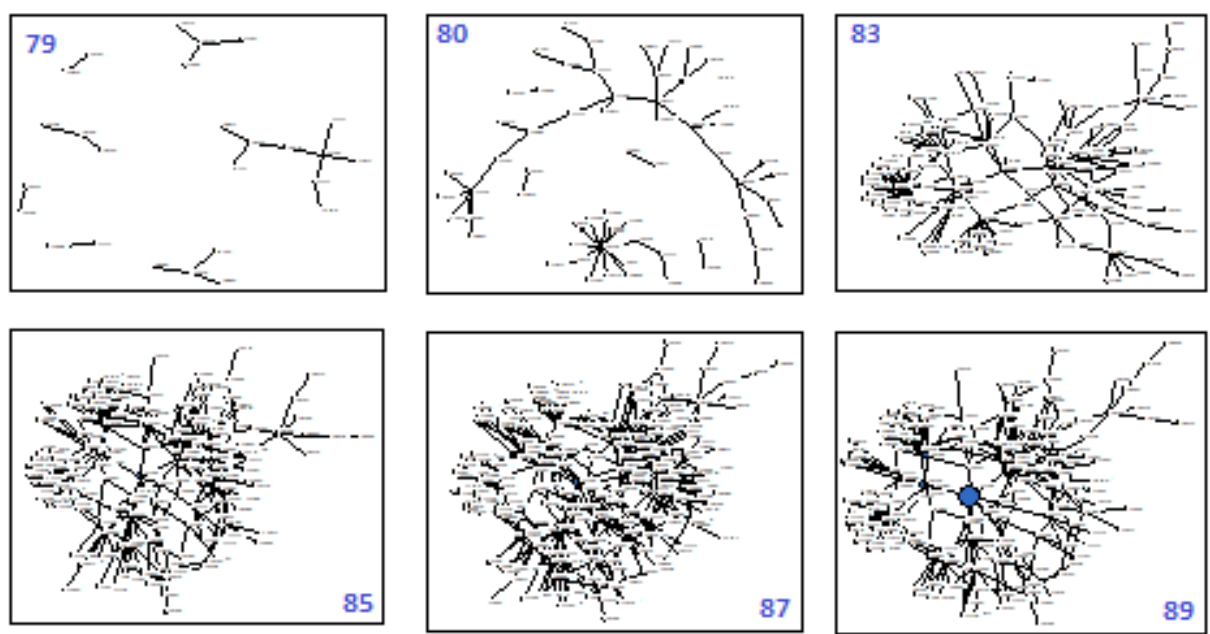